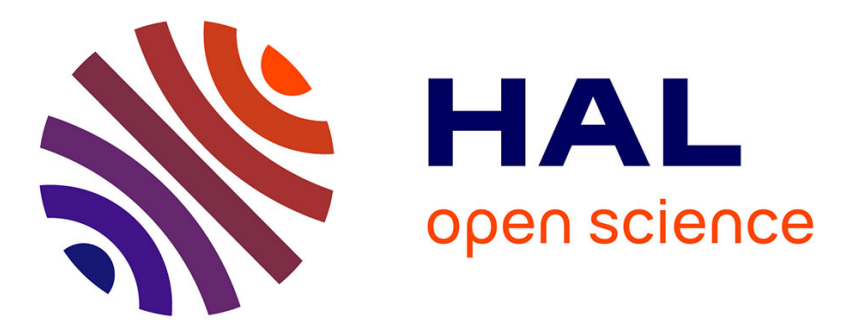

\title{
NOx storage and reduction properties of Pt/CexZr1-xO2 mixed oxides: Sulfur resistance and regeneration, and ammonia formation
}

N. Le Phuc, E.C. Corbos, Xavier Courtois, F. Can, P. Marecot, D. Duprez

\section{To cite this version:}

N. Le Phuc, E.C. Corbos, Xavier Courtois, F. Can, P. Marecot, et al.. NOx storage and reduction properties of $\mathrm{Pt} / \mathrm{CexZr1-xO2}$ mixed oxides: Sulfur resistance and regeneration, and ammonia formation. Applied Catalysis B: Environmental, 2009, 93 (1-2), pp.12-21. 10.1016/j.apcatb.2009.09.007 . hal-03108338

\section{HAL Id: hal-03108338 \\ https://hal.science/hal-03108338}

Submitted on 13 Jan 2021

HAL is a multi-disciplinary open access archive for the deposit and dissemination of scientific research documents, whether they are published or not. The documents may come from teaching and research institutions in France or abroad, or from public or private research centers.
L'archive ouverte pluridisciplinaire HAL, est destinée au dépôt et à la diffusion de documents scientifiques de niveau recherche, publiés ou non, émanant des établissements d'enseignement et de recherche français ou étrangers, des laboratoires publics ou privés. 
Applied Catalysis B: Environmental 93 (2009) 12-21.

DOI: 10.1016/j.apcatb.2009.09.007

\title{
NOx storage and reduction properties of $\mathrm{Pt} / \mathrm{Ce}_{x} \mathrm{Zr}_{1-\mathrm{x}} \mathrm{O}_{2}$ mixed oxides: sulfur resistance and regeneration, and ammonia formation.
}

\author{
N. Le Phuc, E.C. Corbos, X. Courtois*, F. Can, P. Marecot, D. Duprez \\ Laboratoire de Catalyse en Chimie Organique, Université de Poitiers, UMR6503 CNRS, \\ 40 Av. Recteur Pineau, Poitiers, 86022, France \\ *Corresponding author: E-mail: xavier.courtois@univ-poitiers.fr
}

\begin{abstract}
$\underline{\text { Abstract }}$
The influence of the ceria-zirconia mixed oxide composition in $\mathrm{Pt} / \mathrm{Ce}_{\mathrm{x}} \mathrm{Zr}_{1-\mathrm{x}} \mathrm{O}_{2}$ catalysts was studied toward NOx storage capacity, including sulfur poisoning and sulfur regeneration, and NOx reduction efficiency in lean-rich cycling conditions. The results are compared with a $\mathrm{Pt} / \mathrm{Ba} / \mathrm{Al}$ model catalyst. The samples were characterized by $\mathrm{N}_{2}$ adsorption, XRD and $\mathrm{H}_{2}$ - $\mathrm{TPR}$. The behaviors of the ceria-zirconia supported catalysts are quite similar whatever their composition. They are sensitive to a reducing pre-treatment which lead to an increase of (i) the cerium reducibility/oxygen mobility, (ii) the NO oxidation rate and (iii) the NOx storage capacity at 300 and $400^{\circ} \mathrm{C}$. The sulfating treatment leads to a dramatic decrease of the NOx storage capacity for all catalysts, the decrease being more pronounced for the $\mathrm{Zr}$-rich samples. $\mathrm{H}_{2}$-TPR experiments show that the sulfates amount and their stability tend to increase with the $\mathrm{Zr}$ content, but these sulfates are significantly less stable compared with $\mathrm{Pt} / \mathrm{Ba} / \mathrm{Al}$. The sulfur elimination rates in rich mixture at $550^{\circ} \mathrm{C}$ are higher than $90 \%$ with the ceria-zirconia supported catalysts versus $56 \%$ with $\mathrm{Pt} / \mathrm{Ba} / \mathrm{Al}$.

The ceria-zirconia supported catalysts are able to convert NOx in lean-rich cycling condition. Compared with $\mathrm{Pt} / \mathrm{Ba} / \mathrm{Al}$, the NOx conversions are a little lowered but the ammonia selectivity is significantly decreased with the Ce-Zr mixed oxides, with a beneficial influence of the cerium content.
\end{abstract}

Keywords: NOx, storage, reduction, ceria, zirconia, ammonia formation 


\section{Introduction:}

The general demand for lower $\mathrm{CO}_{2}$ emissions leads to the development of diesel and lean-burn engines. Exhaust gases from these engines contain $\mathrm{NO}_{\mathrm{x}}$ in excess of $\mathrm{O}_{2}$, which makes $\mathrm{NO}_{\mathrm{x}}$ reduction into $\mathrm{N}_{2}$ very difficult. One possible way to reduce NOx emissions is to use a NOx storage reduction (NSR) catalyst [1]. It works mainly in lean condition, and the NOx are then oxidized on the precious metals and stored on basic compounds, mainly as nitrates. Periodically, the system switches to rich conditions for few seconds, and the nitrates previously formed during the first step are reduced into $\mathrm{N}_{2}$ on the precious metals [2,3]. The most investigated systems are Pt based catalysts supported on alumina and barium oxide is added as NOx storage material. One of the disadvantages of this catalyst is the deactivation, mainly due to sulfur poisoning and to thermal aging.

Sulfur poisoning [4] is coming from the combustion of sulfur molecules present in fuels and oils, leading to $\mathrm{SO}_{2}$ in the exhaust gas. In oxidizing atmosphere $\mathrm{SO}_{2}$ is oxidized into $\mathrm{SO}_{3}$ which is trapped as sulfate on the NOx storage sites. Unfortunately, the sulfates are more strongly adsorbed than the corresponding nitrates. Then, the regeneration of a poisoned catalyst needs high temperature in rich atmosphere [5], inducing an overconsumption. Moreover, very stable barium sulfate can be formed under oxidizing atmosphere at high temperature, with formation of bulk sulfate [5].

High temperatures not only lead to sulfate stabilization when barium is poisoned, but also to sintering of the precious metals and storage material. For barium/alumina catalysts, formation of $\mathrm{BaAl}_{2} \mathrm{O}_{4}$ (spinel structure) is also observed [6].

Numerous studies were focused on the storage material in order to improve the NOx storage catalysts. For instance, Huang et al. have shown a good sulfur resistance of a Pt- Rh/TiO$/ \mathrm{Al}_{2} \mathrm{O}_{3}$ catalyst [7]. However, barium is the most commonly used storage material and some sulfur tolerance was obtained by addition of other oxides. Yamazaki et al. have studied the impact of $\mathrm{Fe}, \mathrm{Co}, \mathrm{Ni}$ and $\mathrm{Cu}$ addition. They have observed the best beneficial effect with the iron addition which was attributed to inhibition of the bulk $\mathrm{BaSO}_{4}$ formation [8]. Tin addition to barium in order to form $\mathrm{a} \mathrm{BaSnO}_{3}$ perovskites can also lead to a sulfur tolerance for low temperature applications $\left(100-300^{\circ} \mathrm{C}\right)$ [9]. More recently, it has been demonstrated that a $\mathrm{Mg}$-Ba storage material exhibits a high resistance to deactivation by $\mathrm{SO}_{2}$ [10]. However, the roles of cerium compounds, which are largely used in automotive catalysts, are not extensively studied yet in NSR system. They are thought to intervene in the different steps of the NOx trap process: NO oxidation, NOx storage; and NOx reduction. The cerium compounds probably accelerate the hydrocarbon partial oxidation during rich-spikes (giving $\mathrm{CO}$ and $\mathrm{H}_{2}$ as $\mathrm{NOx}$ reducers). This beneficial effect competes with the reduction of the materials itself due to its oxygen storage capacity (OSC), that may delay HC decomposition and thus NOx reduction [1]. However, some results show that cerium compounds in NOx-trap system can lead to interesting properties. First, they improve the barium stability. Eberhardt et al. [11] have compared the behavior of $\mathrm{Ba} / \mathrm{Al}_{2} \mathrm{O}_{3}$ and $\mathrm{Ba} / \mathrm{CeO}_{2}$ materials. No solid/solid reaction between $\mathrm{Ba}$ and ceria was observed below $780^{\circ} \mathrm{C}$ under air, while $\mathrm{Ba}$ reacted at lower temperature with $\mathrm{Al}_{2} \mathrm{O}_{3}$ to form inactive barium aluminates. These results are not totally in accordance with those of Casapu et al. [12]. They have shown that the barium cerate formation is easier than the barium aluminates formation, but they also demonstrated that $\mathrm{BaCeO}_{3}$ is easily decomposed under $\mathrm{NO}_{2}-\mathrm{H}_{2} \mathrm{O}(300-$ $500^{\circ} \mathrm{C}$ temperature range) and destabilized under $\mathrm{CO}_{2}$, whereas $\mathrm{BaAl}_{2} \mathrm{O}_{4}$ is stable. Liotta et al. 
[13] have also observed interaction between cerium and barium compounds in a $\mathrm{Pt}-\mathrm{CeZrOx} / \mathrm{Ba}-$ $\mathrm{Al}_{2} \mathrm{O}_{3} \mathrm{NOx}$-trap catalyst, with a migration of $\mathrm{Ba}$ ions through the CeZrOx compound. This $\mathrm{Ba}-$ $\mathrm{Ce}$ interaction could allow a better control of the $\mathrm{Ba}$ dispersion as well as an improvement of the resistance to $\mathrm{SO}_{2}$ poisoning [14]. Furthermore, it was also previously established that ceria compounds are able to store $\mathrm{NOx}$. The $\mathrm{NO} / \mathrm{O}_{2}$ adsorption on pure ceria was studied by Philipp et al. [15] and the cerium-based compounds participation for the NO storage was putted in evidence in several studies $[13,16]$. For example, $\mathrm{Ba} / \mathrm{CeO}_{2}$ material has exhibited a higher $\mathrm{NOx}$ storage efficiency than $\mathrm{Ba} / \mathrm{Al}_{2} \mathrm{O}_{3}$ within the temperature range of $200-400^{\circ} \mathrm{C}$ [11]. Similar results were obtained by Lin et al. [17] who investigated the effect of La or Ce addition on the NOx storage properties of $\mathrm{Pt} / \mathrm{Ba}^{-} \mathrm{Al}_{2} \mathrm{O}_{3}$. Substituting $\mathrm{La}$ for Ce increased the NOx storage capacity from $341 \mu \mathrm{mol} \mathrm{g}^{-1}$ in $\mathrm{Pt}_{2.5} \mathrm{La}_{30.5} \mathrm{Ba}_{33.4} \mathrm{Al}_{100}$ to $1020 \mu \mathrm{mol} \mathrm{g}^{-1}$ for the $\mathrm{Pt}_{2.5} \mathrm{Ce}_{30.5} \mathrm{Ba}_{33.4} \mathrm{Al}_{100}$ catalyst. Nakatsuji et al. [18] have studied the effect of cerium-based materials on rhodium catalysts deposited on $\mathrm{Ce}, \mathrm{Ce}-\mathrm{Zr}$, Ce-Pr, Ce-Nd-Pr and Ce-Gd-Zr oxides. Compared to $\mathrm{Al}_{2} \mathrm{O}_{3}, \mathrm{ZrO}_{2}$ or beta zeolite, these catalysts allow a high DeNOx activity under lean-rich $(55 \mathrm{~s}-5 \mathrm{~s})$ cycling condition, even in large $\mathrm{O}_{2}$ excess during the lean period.

It is important to note that the optimal storage temperature is depending on the storage material. In a previous study, we have compared the NOx storage capacities of $\mathrm{Pt} / \mathrm{Ce}_{0.7} \mathrm{Zr}_{0.3} \mathrm{O}_{2}$ with a usual $\mathrm{Pt} / \mathrm{Ba} / \mathrm{Al}_{2} \mathrm{O}_{3}$ model catalyst and with $\mathrm{Pt} / \mathrm{Ba} / \mathrm{Ce}_{0.7} \mathrm{Zr}_{0.3} \mathrm{O}_{2}$. At low temperature $\left(200^{\circ} \mathrm{C}\right), \mathrm{Pt} /$ $\mathrm{Ce}_{0.7} \mathrm{Zr}_{0.3} \mathrm{O}_{2}$ exhibited the higher NOx storage capacity, whereas at $400^{\circ} \mathrm{C}$ the best capacity was obtained with $\mathrm{Pt} / \mathrm{Ba} / \mathrm{Ce}_{0.7} \mathrm{Zr}_{0.3} \mathrm{O}_{2}$ [19]. These results were attributed to different basicity and inducing different competition between $\mathrm{NOx}, \mathrm{CO}_{2}$ and $\mathrm{H}_{2} \mathrm{O}$. The low temperature efficiency of ceria based storage material was also demonstrated with $\mathrm{MnO} x-\mathrm{CeO}_{2}$ oxide [20].

These ceria containing catalysts also exhibited very interesting properties especially toward regeneration after sulfating, because the cerium sulfates are less stable than barium sulfates $[14,19,21]$.

Numerous ceria-zirconia compositions are used in automotive catalyst. They are well known for their oxygen storage capacity and their thermal resistance to sintering compared to pure ceria. However, to our knowledge, the impact of the ceria-zirconia composition on the NOx trap behavior was not investigated yet. In the present work, we have studied the NOx storage capacity, the sulfur resistance and regeneration and the NOx removal efficiency of $\mathrm{Pt} / \mathrm{Ce}_{\mathrm{x}} \mathrm{Zr}_{1-\mathrm{x}} \mathrm{O}_{2}$ oxides with $\mathrm{x}=1 ; 0.70 ; 0.58 ; 0.20$. The results are compared to a $\mathrm{Pt} / 10 \% \mathrm{BaO} / \mathrm{Al}_{2} \mathrm{O}_{3}$ model NSR catalyst. Note that the $10 \% \mathrm{BaO}$ may be not the optimal loading but it allows determining if the DeNOx properties of the ceria-zirconia materials are in the same order of magnitude or not. In fact, numerous studies have been performed on the Ba loading, generally included between 5-30 wt\%, that shown that the Ba content influenced the Pt-Ba proximity, the $\mathrm{Ba}$ dispersion and the surface basicity of the catalysts [22,23]. One of the most studied catalysts remains $\mathrm{Pt} / \mathrm{Ba} / \mathrm{Al}$, which can be used as material of reference.

\section{Experimental:}

\subsection{Catalysts preparation}

$\mathrm{A} \mathrm{CeO} 2$ oxide and three $\mathrm{Ce}_{\mathrm{x}} \mathrm{Zr}_{1-\mathrm{x}} \mathrm{O}_{2}$ solid solutions $(\mathrm{x}=0.70 ; 0.58 ; 0.20)$, all provided by Rhodia, were used in this work as catalyst support. They were first calcined 4 hours under air at $700^{\circ} \mathrm{C}$ before use. Platinum was then impregnated with a $\mathrm{Pt}\left(\mathrm{NH}_{3}\right)_{2}\left(\mathrm{NO}_{2}\right)_{2}$ solution in order 
to have $1 \mathrm{wt} \% \mathrm{Pt}$ content. After drying and calcinations under air at $450^{\circ} \mathrm{C}$, the samples were stabilized 4 hours at $700^{\circ} \mathrm{C}$ under a $\mathrm{O}_{2}, \mathrm{H}_{2} \mathrm{O}, \mathrm{N}_{2}$ mixture. The catalysts are noted $\mathrm{Pt} / \mathrm{CeX}$ $(\mathrm{X}=100,70,58,20)$ depending on the ceria content in the support, i.e. for $\mathrm{x}=1 ; 0.70 ; 0.58$; 0.20 in $\mathrm{Ce}_{\mathrm{x}} \mathrm{Zr}_{1-\mathrm{x}} \mathrm{O}_{2}$, respectively.

A reference $1 \mathrm{wt} \% \mathrm{Pt} / 10 \mathrm{wt} \% \mathrm{BaO} / \mathrm{Al}_{2} \mathrm{O}_{3}$ catalyst was prepared by impregnation of an alumina support with a barium nitrate solution. After calcination of the support at $700^{\circ} \mathrm{C}$ under air, platinum was impregnated with a $\mathrm{Pt}\left(\mathrm{NH}_{3}\right)_{2}\left(\mathrm{NO}_{2}\right)_{2}$ solution. The sample was then dried, calcined and stabilized as described above. It is denoted $\mathrm{Pt} / \mathrm{Ba} / \mathrm{Al}$.

To study the impact of a reducing pre-treatment, the catalysts were submitted to pure hydrogen 4 hours at $700^{\circ} \mathrm{C}$ and cooled under $\mathrm{N}_{2}$ until room temperature before exposure to air. These reduced catalysts are denoted $\mathrm{R} 700$.

The catalysts were sulfated by exposure to a 100ppm $\mathrm{SO}_{2}, 10 \% \mathrm{O}_{2}, 10 \% \mathrm{H}_{2} \mathrm{O}$ and $\mathrm{N}_{2}$ mixture at $400^{\circ} \mathrm{C}$ for $5 \mathrm{~h}$. The quantity of $\mathrm{SO}_{2}$ introduced during the sulfating treatment corresponds to a $2.0 \mathrm{wt} \% \mathrm{~S}$ content if all the sulfur is stored on the catalyst. These sulfated catalysts are denoted $+\mathrm{S}$.

The regeneration of the sulfated catalysts was performed under reducing condition with $2.5 \%$ $\mathrm{H}_{2}, 10 \% \mathrm{CO}_{2}, 10 \% \mathrm{H}_{2} \mathrm{O}$ and $\mathrm{N}_{2}$. The catalyst is heated under this mixture from room temperature up to the regeneration temperature $\left(450,500\right.$ or $550^{\circ} \mathrm{C}$, heating rate: $\left.10^{\circ} \mathrm{C} \cdot \mathrm{min}^{-1}\right)$ and maintained at this temperature for 30 min before cooling under $\mathrm{N}_{2}$. The regenerated catalysts are denoted $+\mathrm{R} 450,+\mathrm{R} 500$ or $+\mathrm{R} 550$, respectively.

Some aging were also performed before or after the sulfating treatment. The sample was submitted to a mixture containing $10 \% \mathrm{O}_{2}, 10 \% \mathrm{CO}_{2}, 10 \% \mathrm{H}_{2} \mathrm{O}$ and $\mathrm{N}_{2}$ at $800^{\circ} \mathrm{C}$ for $30 \mathrm{~min}$. The corresponding samples are named $+\mathrm{A} 800$.

\subsection{NOx storage capacity (NSC) measurement}

Before the NOx storage capacity measurements, the catalyst $(60 \mathrm{mg})$ was pretreated in situ for $30 \mathrm{~min}$ at $550^{\circ} \mathrm{C}$ (or $300^{\circ} \mathrm{C}$ for the sulfated samples), under a $10 \% \mathrm{O}_{2}, 10 \% \mathrm{H}_{2} \mathrm{O}, 10 \% \mathrm{CO}_{2}$ and $\mathrm{N}_{2}$ mixture (total flow rate: $10 \mathrm{~L} \cdot \mathrm{h}^{-1}$ ), and then cooled down to the storage temperature under the same mixture. The sample was then submitted to 350ppm NO, $10 \% \mathrm{O}_{2}, 10 \% \mathrm{H}_{2} \mathrm{O}, 10 \%$ $\mathrm{CO}_{2}$ and $\mathrm{N}_{2}$ (total flow rate: $10 \mathrm{~L} . \mathrm{h}^{-1}$ ) at $200^{\circ} \mathrm{C}, 300^{\circ} \mathrm{C}$ and $400^{\circ} \mathrm{C}$. The gas flow was introduced using mass-flow controllers, except for $\mathrm{H}_{2} \mathrm{O}$ which was introduced using a saturator. Both $\mathrm{NO}$ and $\mathrm{NOx}$ concentrations $\left(\mathrm{NO}+\mathrm{NO}_{2}\right)$ were followed by chemiluminescence. $\mathrm{H}_{2} \mathrm{O}$ was removed prior to NOx analysis with a membrane dryer. Long time storage is not representative of the NSR catalyst working conditions, since the lean periods are commonly around $1 \mathrm{~min}$. The NOx storage capacity was then estimated by the integration of the recorded profile for the first 100 seconds to minimize the uncertainty due to the subtraction of the reactor volume contribution. With the conditions used in this test, $67 \mu$ mol NOx per gram of catalyst are injected in $100 \mathrm{~s}$. In addition, the platinum oxidation activity was estimated as the $\mathrm{NO}_{2} / \mathrm{NOx}$ ratio (\%) at saturation (usually about 900s).

\subsection{NOx conversion in cycling conditions}

Before measurement, the catalyst $(100 \mathrm{mg})$ was treated in situ at $550^{\circ} \mathrm{C}$ under $10 \% \mathrm{O}_{2}, 10 \%$ $\mathrm{H}_{2} \mathrm{O}, 10 \% \mathrm{CO}_{2}$ and $\mathrm{N}_{2}$. The sample was then cooled down to test temperatures $(200,300$ and $400^{\circ} \mathrm{C}$ ) under the same mixture. The NOx conversion was studied in cycling condition by 
alternatively switching between lean (30s) and rich (10s) conditions using electro-valves. These relatively short lean periods were used to have better evidence of the different behaviors. The gas composition is described in Table 1 . $\mathrm{NO}$ and $\mathrm{NO}_{2}$ were followed by chemiluminescence, $\mathrm{N}_{2} \mathrm{O}$ by specific FTIR, $\mathrm{H}_{2}$ by mass spectrometry. Before the analyzers, $\mathrm{H}_{2} \mathrm{O}$ was removed in a condenser at $0^{\circ} \mathrm{C}$. For each studied temperature, the activity of the catalysts was followed until stabilization. After stabilization, the outlet water was condensed for one hour in a dry condenser and then analyzed by two different $\mathrm{HPLC}$ for $\mathrm{NH}_{4}{ }^{+}, \mathrm{NO}_{2}{ }^{-}$and $\mathrm{NO}_{3}{ }^{-} . \mathrm{NO}_{2}{ }^{-}$and $\mathrm{NO}_{3}{ }^{-}$were added to the unconverted NOx. The $\mathrm{N}_{2}$ selectivity is calculated assuming no other $\mathrm{N}$-compounds than $\mathrm{NO}, \mathrm{NO}_{2}, \mathrm{~N}_{2} \mathrm{O}, \mathrm{NH}_{3}$. Some tests were also performed using a Multigas FTIR detector (MKS 2030) without water trap system.

Table 1: NOx removal efficiency test: gas composition for the lean and rich mixtures. Total flow rate: $167 \mathrm{ml} \cdot \mathrm{min}^{-1}$.

\begin{tabular}{lcccccc}
\hline Gas & $\mathrm{NO}$ & $\mathrm{O}_{2}$ & $\mathrm{H}_{2}$ & $\mathrm{CO}_{2}$ & $\mathrm{H}_{2} \mathrm{O}$ & $\mathrm{N}_{2}$ \\
\hline Lean $(30 \mathrm{~s})$ & $500 \mathrm{ppm}$ & $10 \%$ & - & $10 \%$ & $10 \%$ & Balance \\
\hline Rich (10s) & - & - & 3 or $6 \%$ & $10 \%$ & $10 \%$ & Balance \\
\hline
\end{tabular}

\subsection{Temperature programmed reduction (TPR)}

Prior to the TPR test, the catalyst (50 mg) was first pretreated in situ under oxygen at $300^{\circ} \mathrm{C}$ for $30 \mathrm{~min}$ and cooled to room temperature. After flushing under argon for $45 \mathrm{~min}$, the reduction was carried out from room temperature up to $800^{\circ} \mathrm{C}$ under a $1 \% \mathrm{H}_{2} / \mathrm{Ar}$ mixture, using a $5^{\circ} \mathrm{C}$ $\mathrm{min}^{-1}$ heating rate. The sample was maintained at $800^{\circ} \mathrm{C}$ for $30 \mathrm{~min}$ before cooling under argon. Hydrogen consumption was followed by thermal conductivity.

\subsection{X-ray diffraction}

$\mathrm{X}$-ray powder diffraction was performed at room temperature with a Bruker D5005 using a K $\alpha$ $\mathrm{Cu}$ radiation $(\lambda=1.54056 \AA$ ). The powder was deposited on a silicon monocrystal sample holder. The crystalline phases were identified by comparison to the ICDD database files.

\subsection{Specific surface measurement}

The BET surface areas were deduced from $\mathrm{N}_{2}$ adsorption at $-196^{\circ} \mathrm{C}$ carried out with a Micromeritics apparatus. Prior to the measurement, the samples were treated at $250^{\circ} \mathrm{C}$ under vacuum for $8 \mathrm{~h}$ to eliminate the adsorbed species.

\subsection{Oxygen storage capacity (OSC)}

The OSC was measured at $200,300400^{\circ} \mathrm{C}$ under atmospheric pressure. The sample $(5 \mathrm{mg})$ was continuously purged with helium $\left(30 \mathrm{~mL} \cdot \mathrm{min}^{-1}\right)$. Alternate pulses $(0.265 \mathrm{~mL})$ of pure $\mathrm{O}_{2}$ and pure CO were injected every 2 min [24]. The oxygen storage capacity (OSC) was calculated from the $\mathrm{CO}$ consumption after stabilization. 


\section{Results and discussion:}

\subsection{BET and XRD}

Table 2 shows the BET surface area of the catalysts after the different treatments. The stabilized ceria-zirconia supported catalysts exhibit similar areas, between 61 and $63 \mathrm{~m}^{2} \cdot \mathrm{g}^{-1}$. The reduction and the aging treatments induce a small decrease of $5-10 \%$ and $5-8 \%$, respectively. The zirconia-rich sample is the more stable ceria-zirconia sample toward reduction, and the less stable toward aging. The sulfating treatment is a little more severe, with a loss between $13 \%$ and $18 \%$. After aging and consecutive sulfating treatment, the decrease of the surface area is more significant, until 36-38\% for $\mathrm{Pt} / \mathrm{Ce} 70$ and $\mathrm{Pt} / \mathrm{Ce} 58$. Representative diffractogramms, obtained with Pt/Ce70, are reported Figure 1. The XRD data of the Pt/CeX catalysts are in agreement with the BET measurements. Whatever the treatment, the width of the main peak, which is related to the mean particle size, is rather constant for the ceria-zirconia based catalysts, except after sulfating and aging. A small decrease is then observed. The average particle size deduced from the Scherrer equation are $7.6 \mathrm{~nm}, 8.2 \mathrm{~nm}$ and $9.3 \mathrm{~nm}$ for the stabilized, the reduced, and the sulfated and consecutively aged Pt/Ce70 catalysts, respectively. In the latter case, in addition to the sintering, a pore filing by sulfates can occur, in accordance with the decrease of the surface areas of the sulfated samples.

Concerning the pure ceria supported sample, a high surface area is observed after stabilization, at $94 \mathrm{~m}^{2} \cdot \mathrm{g}^{-1}$ (Table 2). However, this catalyst is more sensitive to the different treatments than the ceria-zirconia supported samples. The sulfating treatment leads to a loss of $34 \%$ of the initial surface area, and a dramatically collapse is observed after the reduction treatment $(-80 \%)$. The XRD patterns of the stabilized and reduced Pt/Ce100 samples (Figure 1) are in accordance with these results. The mean particle size greatly increases after the reducing treatment, from $8.8 \mathrm{~nm}$ to $20.3 \mathrm{~nm}$ using the Scherrer equation. The oxidizing treatment at $800^{\circ} \mathrm{C}$ also leads to a severe sintering ( $-55 \%$ for the surface area), and a sulfating and consecutive aging treatment induces a stronger decrease of the surface area, at only $18 \mathrm{~m}^{2} \cdot \mathrm{g}^{-1}$ (Table 2).

With all these catalysts, note that there is no supplementary surface loss after the desulfating treatment, a small recovery of few $\mathrm{m}^{2} \cdot \mathrm{g}^{-1}$ can be observed (not reported in Table 2), which is in agreement with a pore filling by sulfates.

$\mathrm{The} \mathrm{Pt} / \mathrm{Ba} / \mathrm{Al}$ catalyst surface area is not affected by these different treatments, at around 118 $\mathrm{m}^{2} \mathrm{~g}^{-1}$. However, it has been previously established with this catalyst [5] that aging at $800^{\circ} \mathrm{C}$ favors the barium aluminates formation while aging after sulfating leads to bulk barium sulfate formation. 
Table 2: BET surface areas $\left(\mathrm{m}^{2} \cdot \mathrm{g}^{-1}\right)$ of the studied catalysts.

BET surface areas $\left(\mathrm{m}^{2} \cdot \mathrm{g}^{-1}\right)$

\begin{tabular}{lccccc}
\hline Catalyst & $\begin{array}{c}\text { Stabilized } \\
\left(700^{\circ} \mathrm{C}\right)\end{array}$ & $\begin{array}{c}\text { Reduced } \\
\left(700^{\circ} \mathrm{C}\right)\end{array}$ & Sulfated & $\begin{array}{c}\text { Aged } \\
\left(800^{\circ} \mathrm{C}\right)\end{array}$ & $\begin{array}{c}\text { Sulfated and } \\
\text { aged }\end{array}$ \\
\hline $\mathrm{Pt} / \mathrm{Ce} 100$ & 94 & 18 & 62 & 42 & 18 \\
\hline $\mathrm{Pt} / \mathrm{Ce} 70$ & 61 & 55 & 52 & 57 & 38 \\
\hline $\mathrm{Pt} / \mathrm{Ce} 58$ & 62 & 55 & 51 & 59 & 40 \\
\hline $\mathrm{Pt} / \mathrm{Ce} 20$ & 63 & 60 & 55 & 58 & 49 \\
\hline $\mathrm{Pt} / \mathrm{Ba} / \mathrm{Al}$ & 118 & - & 118 & 119 & 117 \\
\hline
\end{tabular}

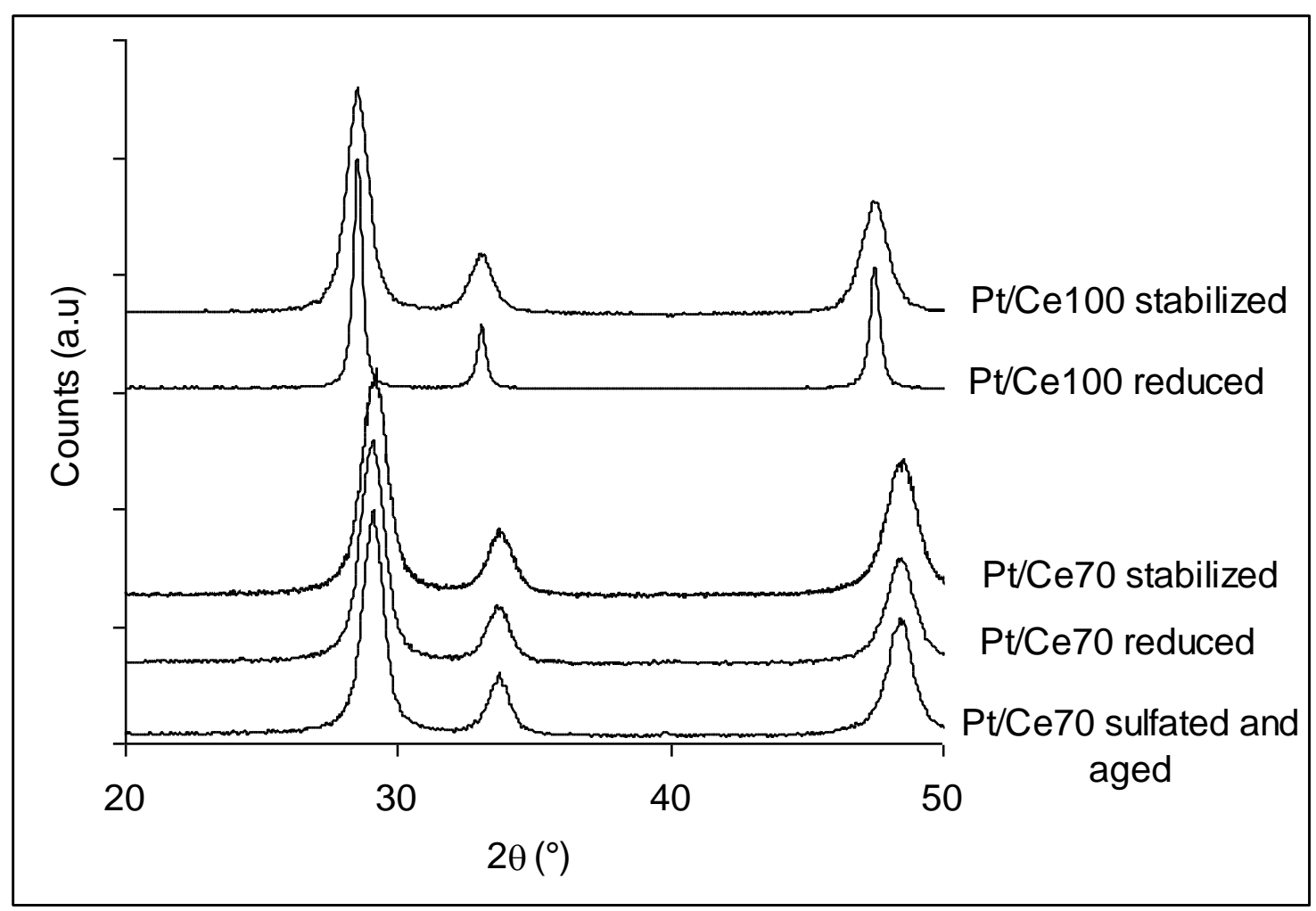

Figure 1: $\mathrm{X}$ ray diffractogramms of $\mathrm{Pt} / \mathrm{Ce} 70$ and $\mathrm{Pt} / \mathrm{Ce} 100$ after stabilization, after reduction (R700) and after sulfating and aging (+S+A800). 


\subsubsection{Stabilized catalysts}

The NOx storage capacities (NSC) of the stabilized catalysts were measured at 200, 300 and $400^{\circ} \mathrm{C}$ in lean mixture containing $\mathrm{H}_{2} \mathrm{O}$ and $\mathrm{CO}_{2}$. The results for a storage time of $100 \mathrm{~s}$ are reported in Table 3.

The Pt/Ba/Al catalyst exhibits NSC between $13.1 \mu \mathrm{mol} . \mathrm{g}^{-1}$ at $200^{\circ} \mathrm{C}$ and $18.3 \mu \mathrm{mol} . \mathrm{g}^{-1}$ at $400^{\circ} \mathrm{C}$. These results were discussed in detail in a previous study [23] and were attributed to relatively strong surface basicity. It allows a higher NSC at high temperature due to a good nitrate thermal stability, but it also induces competition with $\mathrm{H}_{2} \mathrm{O}$ and especially $\mathrm{CO}_{2}$. Same evolution with temperature is obtained with $\mathrm{Pt} / \mathrm{Ce} 100$, which indicates the presence of relatively strong basic sites too. Some changes occur with the ceria-zirconia supported samples. The NSC of Pt/Ce70 is nearly constant with the temperature test, and the optimal temperature is observed at $200^{\circ} \mathrm{C}$ for $\mathrm{Pt} / \mathrm{Ce} 58$ and $\mathrm{Pt} / \mathrm{Ce} 20$. Then, the optimal storage temperature decreases with the increase of the $\mathrm{Zr}$ content. Therefore, the increase of the zirconia content induces a weaker basicity. The $\mathrm{NO}$ oxidation activity, expressed as the $\mathrm{NO}_{2} / \mathrm{NOx}$ ratio at saturation is reported in Figure 2. No correlation was observed between the NSC and the NO oxidation activity. Actually, the influence of the support composition is rather limited but the $\mathrm{NO}_{2} / \mathrm{NOx}$ ratio strongly increases with the temperature test. It is very low at $200^{\circ} \mathrm{C}$, generally below $10 \%$, and increases near $30 \%$ at $400^{\circ} \mathrm{C}$ (Figure 2).

Compared to $\mathrm{Pt} / \mathrm{Ba} / \mathrm{Al}$, the higher NSC of $\mathrm{Pt} / \mathrm{Ce} 100$ can be attributed to the fact that the entire support surface may participate to the NOx storage, whereas it occurs mainly on the Ba surface on $\mathrm{Pt} / \mathrm{Ba} / \mathrm{Al}$. The NSC of the ceria-zirconia supported catalysts are a little lower than with $\mathrm{Pt} / \mathrm{Ce} 100$, but their specific areas are 30\% lower. In order to observe if a correlation exists between the NSC behavior and the redox properties, the samples characterized by $\mathrm{H}_{2}-\mathrm{TPR}$.

Table 3: NOx storage capacities calculated for the first 100 seconds $\left(\mu \mathrm{mol} . \mathrm{g}^{-1}\right)^{*}$. Influence of the temperature test and the catalyst treatment (stabilized or reduced catalysts).

\begin{tabular}{lcccccc}
\hline Catalyst & \multicolumn{2}{c}{$\begin{array}{r}\text { NOx storage capacity }\left(\mu \mathrm{mol} . \mathrm{g}^{-1}\right) \\
\text { stabilized catalysts }\end{array}$} & \multicolumn{3}{c}{$\begin{array}{c}\text { NOx storage capacity }\left(\mu \mathrm{mol}^{-1} \mathrm{~g}^{-1}\right) \\
\text { reduced catalysts R700 }\end{array}$} \\
\hline temperature & $200^{\circ} \mathrm{C}$ & $300^{\circ} \mathrm{C}$ & $400^{\circ} \mathrm{C}$ & $200^{\circ} \mathrm{C}$ & $300^{\circ} \mathrm{C}$ & $400^{\circ} \mathrm{C}$ \\
\hline $\mathrm{Pt} / \mathrm{Ce} 100$ & 20.9 & 22.8 & 24.2 & 8.7 & 14.0 & 9.6 \\
\hline $\mathrm{Pt} / \mathrm{Ce} 70$ & 17.1 & 16.9 & 16.7 & 19.4 & 23.1 & 21.3 \\
\hline $\mathrm{Pt} / \mathrm{Ce} 58$ & 23.0 & 17.4 & 15.5 & 23.2 & 24.9 & 19.8 \\
\hline $\mathrm{Pt} / \mathrm{Ce} 20$ & 18.1 & 16.0 & 12.8 & 19.3 & 21.1 & 16.6 \\
\hline $\mathrm{Pt} / \mathrm{Ba} / \mathrm{Al}$ & 13.1 & 13.8 & 18.3 & & & \\
\hline
\end{tabular}

* $67 \mu \mathrm{mol} . \mathrm{g}^{-1}$ are injected in $100 \mathrm{~s}$ 


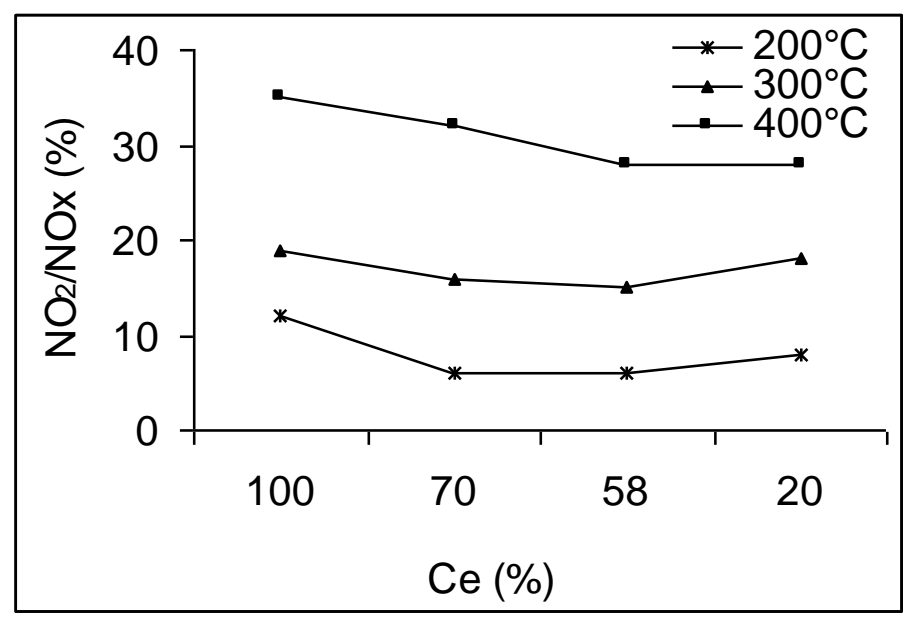

Figure 2: NOx storage test: $\mathrm{NO}_{2} / \mathrm{NOx}$ ratio at saturation (stabilized catalysts) depending on the ceria-zirconia support composition.

The TPR profiles of the Pt/CeX catalysts are reported in Figure 3. A main reduction peak is observed in the $120-300^{\circ} \mathrm{C}$ temperature range, depending on the material composition. It corresponds to the easily reducible $\mathrm{Ce}^{\mathrm{IV}}$ reduction in $\mathrm{Ce}^{\mathrm{III}}$. The higher the zirconium content is, the lower the temperature peak is (maxima between 180 and $260^{\circ} \mathrm{C}$ ). The corresponding $\mathrm{H}_{2}$ consumptions $\left(\mu \mathrm{mol} . \mathrm{g}^{-1}\right)$ are plotted in Figure 4A. The Pt/Ce58 and Pt/Ce70 catalysts exhibit the highest reducibility. Nevertheless, there is no direct correlation between this parameter, which is linked to the oxygen mobility and would influence the NO oxidation, and the NOx storage capacity.

However, ceria containing catalysts are known for their redox properties. Then, a reducing pretreatment may modify the NOx storage behaviors.

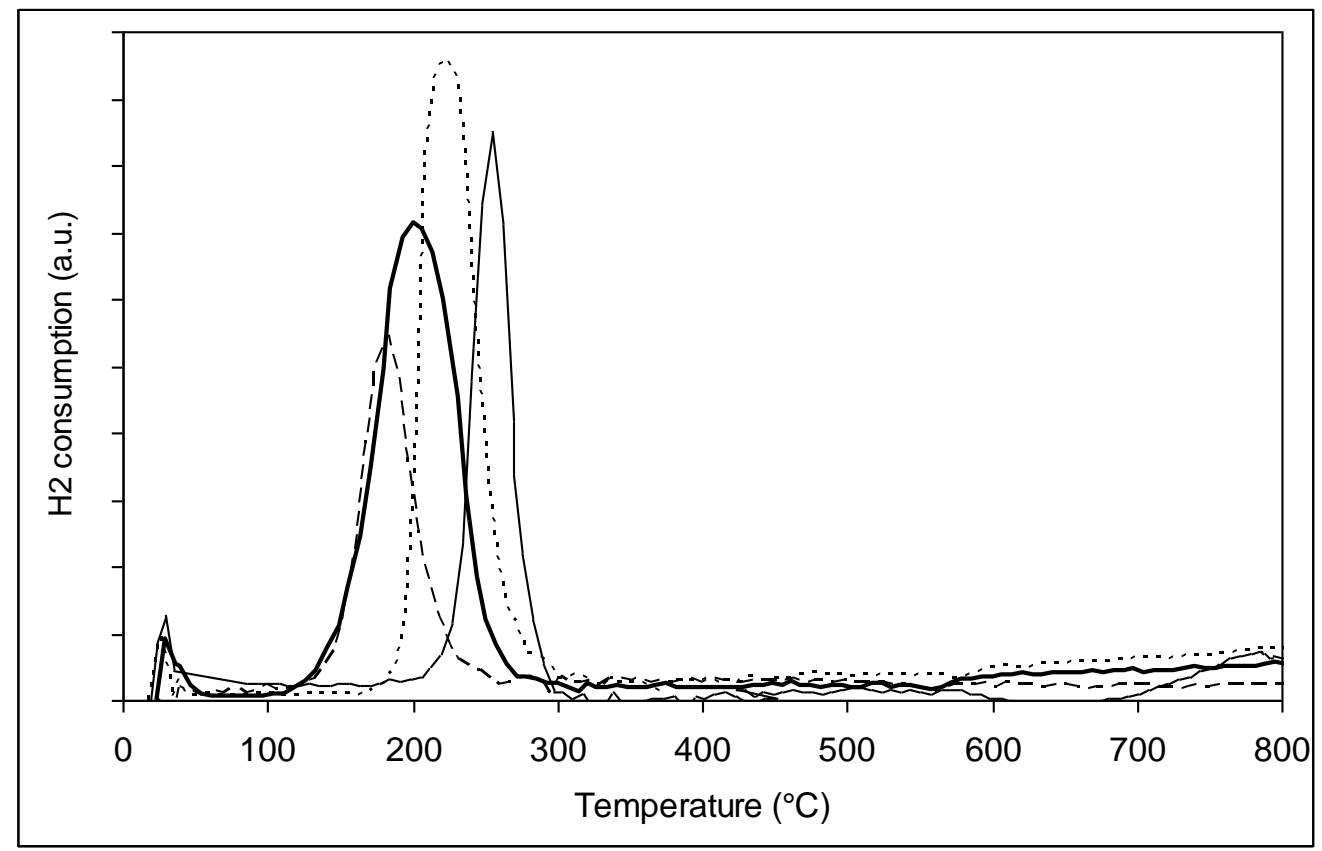

Figure 3: TPR profiles of the Pt/CeX stabilized catalysts: Pt/Ce100 (-), Pt/Ce70 (*), Pt/Ce58 (一) and Pt/Ce20 (---). 

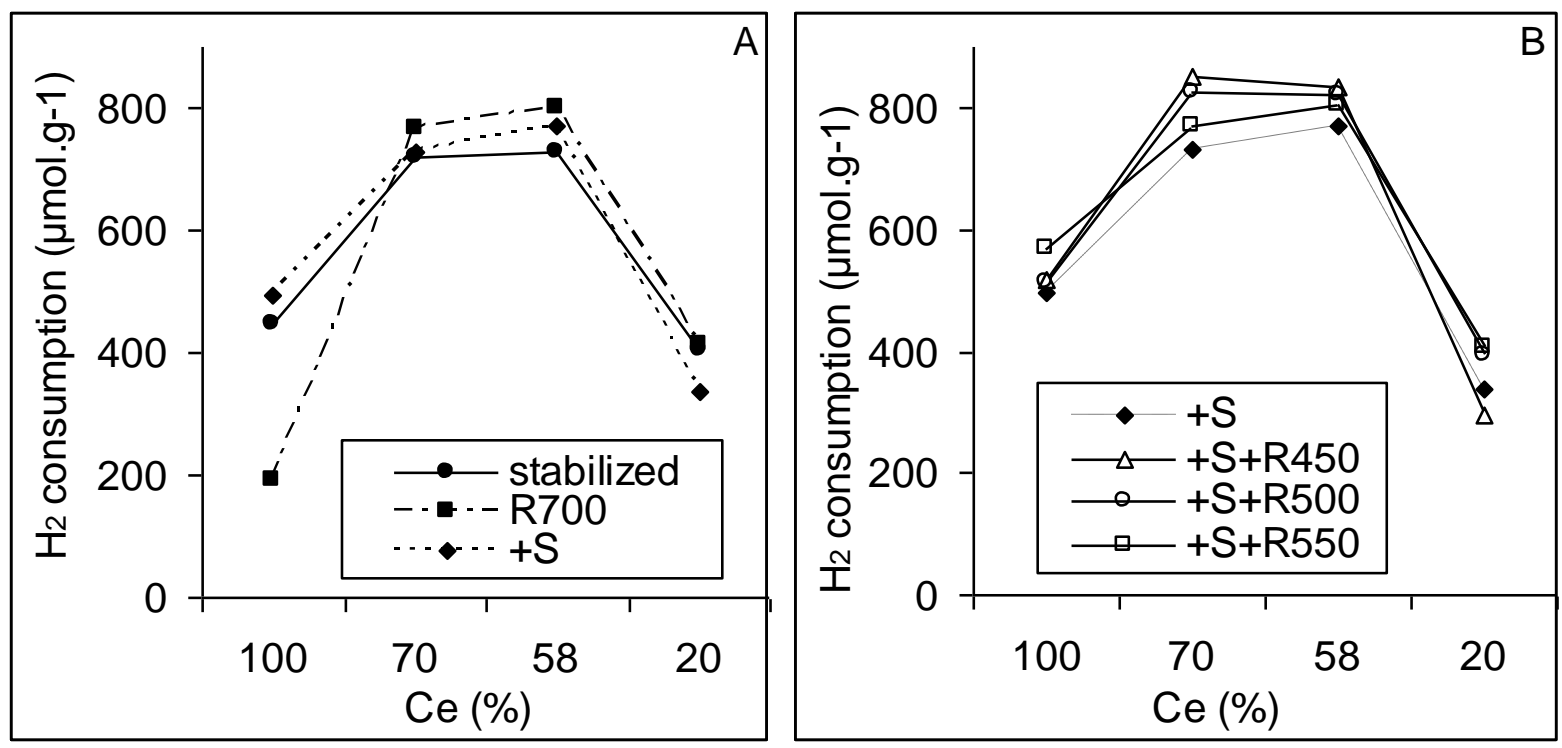

Figure 4: $\mathrm{H}_{2}$ consumptions ( $\mu$ mol.g ${ }^{-1}$ ) corresponding to the "easily" reducible $\mathrm{Ce}^{\mathrm{IV}}$ of the $\mathrm{Pt} / \mathrm{CeX}$ catalysts deduced from the TPR measurements $\left(100^{\circ} \mathrm{C}<\mathrm{Tr}<350^{\circ} \mathrm{C}\right)$. A) stabilized catalyst $(\bullet)$, reduced catalyst $\mathrm{R} 700(\boldsymbol{\square})$, sulfated catalyst $+\mathrm{S}(\bullet)$; B) sulfated catalyst $+\mathrm{S}(\bullet)$, after regeneration at $450^{\circ} \mathrm{C}(\triangle)$, after regeneration at $450^{\circ} \mathrm{C}(\mathrm{\circ})$, after regeneration at $450^{\circ} \mathrm{C}$ (口).

\subsubsection{Reduced catalysts (R700)}

The NOx storage capacities of the reduced ceria-zirconia supported catalysts are reported in Table 3. Compared with the stabilized samples, the NOx storage capacities are nearly unchanged at $200^{\circ} \mathrm{C}$ but raise at 300 and $400^{\circ} \mathrm{C}$ with a mean increase of $37 \%$ and $28 \%$, respectively. Then, the optimal storage temperature is shifted from $200^{\circ} \mathrm{C}$ (stabilized catalysts) up to $300^{\circ} \mathrm{C}$ (reduced catalysts), which would mean that the reducing treatment induces a small increase of the catalysts basicity.

At $300^{\circ} \mathrm{C}$, the NOx storage capacities of the ceria-zirconia supported catalysts reach values between 21.1 and $24.9 \mu \mathrm{mol} . \mathrm{g}^{-1}$. On the contrary, the $\mathrm{Pt} / \mathrm{Ce} 100$ sample exhibits a strong decrease of the NOx storage capacity $(-40 \%)$ after reduction which is attributed to the dramatic decrease of the surface area (Table 2).

This NOx storage improvement after the reducing treatment can be attributed to higher oxidation properties since the $\mathrm{NO}$ oxidation activity also increases. Indeed, the $\mathrm{NO}_{2} / \mathrm{NOx}$ ratio (\%) at saturation, reported in Table 4 for the tests at $300^{\circ} \mathrm{C}$, significantly increases on the R700 samples, especially for the high cerium loading compositions. For instance, it increases from $15-16 \%$ to $32-35 \%$ for the $\mathrm{Pt} / \mathrm{Ce} 58$ and $\mathrm{Pt} / \mathrm{Ce} 70$ catalysts. 
Table 4: Influence of the reduction treatment on the $\mathrm{NO}$ oxidation activity at $300^{\circ} \mathrm{C}$, expressed as the $\mathrm{NO}_{2} / \mathrm{NOx}(\%)$ ratio after saturation.

\begin{tabular}{lccccc}
\hline \multicolumn{5}{c}{$\mathrm{NO}_{2} / \mathrm{NOx}(\%)$ at saturation } \\
\hline $\begin{array}{c}\text { Stabilized } \\
\text { catalyst }\end{array}$ & $\mathrm{R} 700$ & Sulfated & $\begin{array}{c}\text { Sulfated } \\
\text { and aged }\end{array}$ & $+\mathrm{S}+\mathrm{R} 550$ \\
\hline $\mathrm{Pt} / \mathrm{Ce} 100$ & 19 & 29 & 20 & 11 & 25 \\
\hline $\mathrm{Pt} / \mathrm{Ce} 70$ & 16 & 32 & 18 & 11 & 20 \\
\hline $\mathrm{Pt} / \mathrm{Ce} 58$ & 17 & 35 & 16 & 13 & 29 \\
\hline $\mathrm{Pt} / \mathrm{Ce} 20$ & 18 & 20 & 18 & 16 & 21 \\
\hline
\end{tabular}

The platinum state should not play an important role for these changes since it may be not so different during the test, depending on the different treatments. On alumina ( $\mathrm{Pt} / \mathrm{Ba} / \mathrm{Al})$, bulk platinum is reduced even after the stabilization treatment at $700^{\circ} \mathrm{C}$ in oxidizing atmosphere. Corresponding Pt X-ray diffraction peak is easily detectable [23]. Platinum is known to be better dispersed/stabilized on CeZr materials due to strong Pt-O-Ce link [25] and neither Pt nor PtO XRD peaks are detected (Figure 1). Moreover, before the NOx storage capacity measurement (as before the NOx conversion test in cycling conditions), the catalysts were pretreated in situ for $30 \mathrm{~min}$ at $550^{\circ} \mathrm{C}$, under a $10 \% \mathrm{O}_{2}, 10 \% \mathrm{H}_{2} \mathrm{O}, 10 \% \mathrm{CO}_{2}$ and $\mathrm{N}_{2}$ mixture (section 2). Then, whatever the previous treatment, we can assume that platinum should be metallic with a partially oxidized surface for alumina supported catalysts, and probably in a little more oxidized state on ceria-zirconia. Finally, the reducing pretreatment should not lead to very different platinum states for the storage test. Beside, in 2004, Perrichon et al. [26] studied the metal dispersion of $\mathrm{CeO}_{2}-\mathrm{ZrO}_{2}$ supported platinum catalysts measured by $\mathrm{H}_{2}$ or $\mathrm{CO}$ chemisorption. It was demonstrated that the platinum dispersion was nearly constant for a wide range of composition of the mixed oxide between $\mathrm{Ce}_{0.15} \mathrm{Zr}_{0.85}$ and $\mathrm{Ce}_{0.68} \mathrm{Zr}_{0.32}$.

To explain the evolutions observed after the reducing treatment, the redox behavior of the reduced samples was investigated by both $\mathrm{H}_{2}$-TPR measurements and oxygen storage capacity (OSC) tests.

After the usual oxidation pretreatment (section 2.4), the TPR profiles of the reduced samples show a shift of the main reduction peak to lower temperature (Figure 5). $\mathrm{The}_{2}$ consumption starts at room temperature and the reduction of the easily reducible $\mathrm{Ce}^{\mathrm{IV}}$ is finished near $150^{\circ} \mathrm{C}$. This improvement of the cerium reducibility in ceria-zirconia materials after a reducing treatment is well known [27,28]. It can be attributed to a structural re-organization of ceriazirconia, and to the reduction of the platinum particles, according to Fan et al. [29].Compared to the stabilized catalysts, there is no significant change of the $\mathrm{H}_{2}$ consumption related to the easily reducible $\mathrm{Ce}^{\mathrm{IV}}$, except for the $\mathrm{Pt} / \mathrm{Ce} 100$ catalyst because of the surface area loss (Figure 4A).

To complete this study, the oxygen storage capacities of the reduced samples were measured at 200,300 and $400^{\circ} \mathrm{C}$ with the CO-pulsed method and the results (Table 5) were compared with the $\mathrm{NO}_{2} / \mathrm{NOx}$ ratio measured at the same temperatures at the end of the storage test. The results 
are reported in Figure 6 and they clearly show a correlation between the oxygen storage capacity, which is linked to the oxygen mobility, and the NO oxidation activity. Note that the better result for each temperature depends on the support composition. The low cerium loading catalyst $\mathrm{Pt} / \mathrm{Ce} 20$ is the more active at low temperature, whereas the best results are obtained with the cerium-rich samples at higher temperature.

Finally, compared to the stabilized samples, the reduced ceria-zirconia supported catalysts exhibit higher NOx storage capacities which can be attributed to an enhancement of the redox behaviors. Particularly, the NO oxidation reaction, which is the first step of the storage process, is largely improved. However, the NO oxidation rate is not the only limiting parameter in this study. Indeed, Pt/Ce20 and Pt/Ce70 catalysts, which exhibit similar surface areas and different redox behaviors, have similar NOx storage properties.

Table 5: Oxygen storage capacities (OSC) $\left(\mu\right.$ molo.g $\left.^{-1}\right)$ measured with the CO-pulsed method at 200,300 and $400^{\circ} \mathrm{C}$. Influence of the catalyst treatment.

\begin{tabular}{lccccccccc}
\hline & \multicolumn{3}{c}{ stabilized } & \multicolumn{3}{c}{ reduced } & \multicolumn{3}{c}{ sulfated } \\
\hline Temp. & $200^{\circ} \mathrm{C}$ & $300^{\circ} \mathrm{C}$ & $400^{\circ} \mathrm{C}$ & $200^{\circ} \mathrm{C}$ & $300^{\circ} \mathrm{C}$ & $400^{\circ} \mathrm{C}$ & $200^{\circ} \mathrm{C}$ & $300^{\circ} \mathrm{C}$ & $400^{\circ} \mathrm{C}$ \\
\hline $\mathrm{Pt} / \mathrm{Ce} 100$ & 116 & 185 & 227 & 20 & 36 & 69 & 24 & 46 & 142 \\
\hline $\mathrm{Pt} / \mathrm{Ce} 70$ & 117 & 488 & 716 & 80 & 327 & 667 & 42 & 238 & 671 \\
\hline $\mathrm{Pt} / \mathrm{Ce} 58$ & 164 & 554 & 752 & 112 & 438 & 638 & 49 & 273 & 663 \\
\hline $\mathrm{Pt} / \mathrm{Ce} 20$ & 103 & 248 & 362 & 96 & 243 & 417 & 20 & 94 & 279 \\
\hline
\end{tabular}




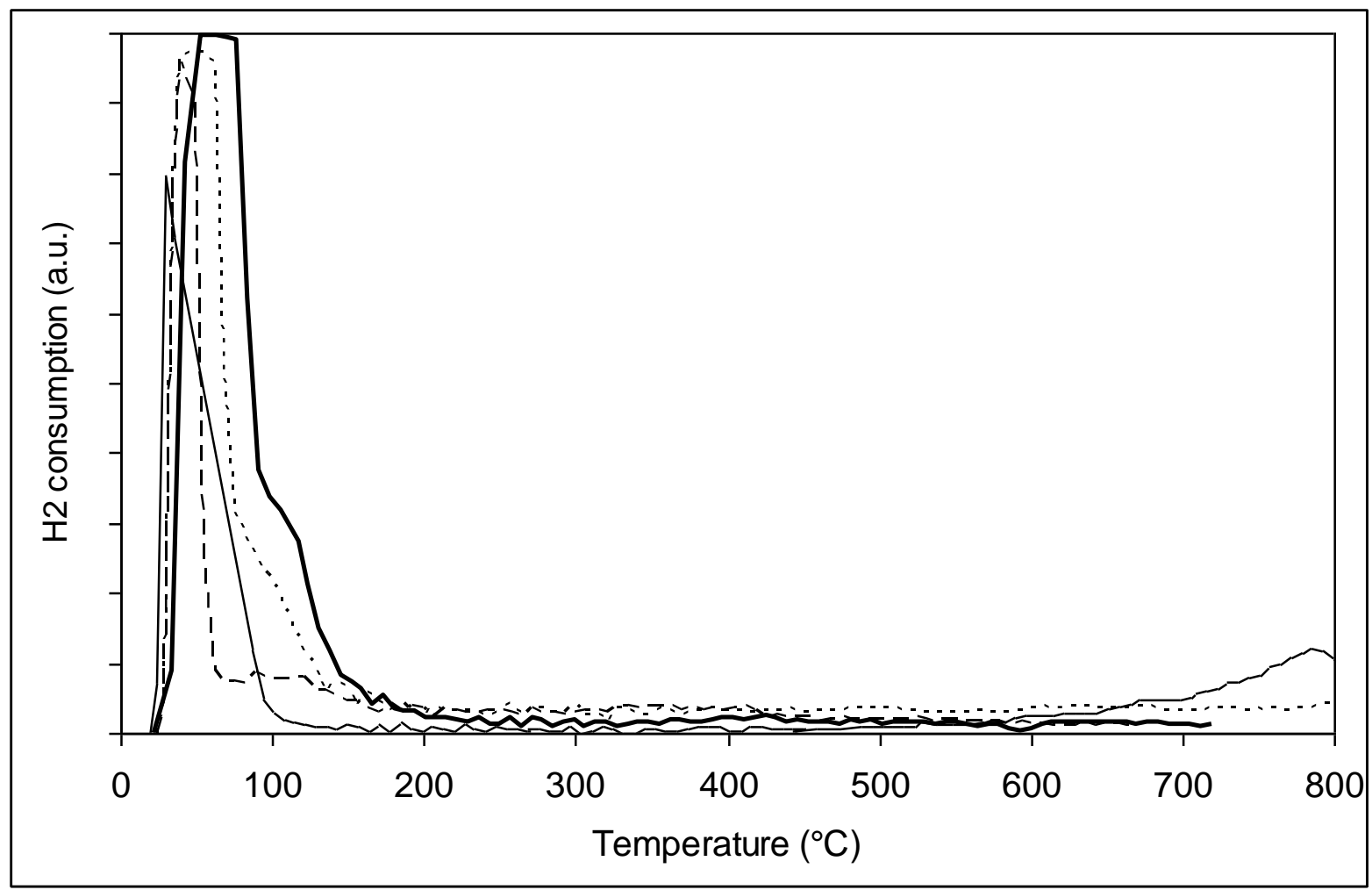

Figure 5: TPR profiles of the reduced (R700) Pt/CeX catalysts: Pt/Ce100 (-), Pt/Ce70 (*), $\mathrm{Pt} / \mathrm{Ce} 58$ (一) and Pt/Ce20 (---)

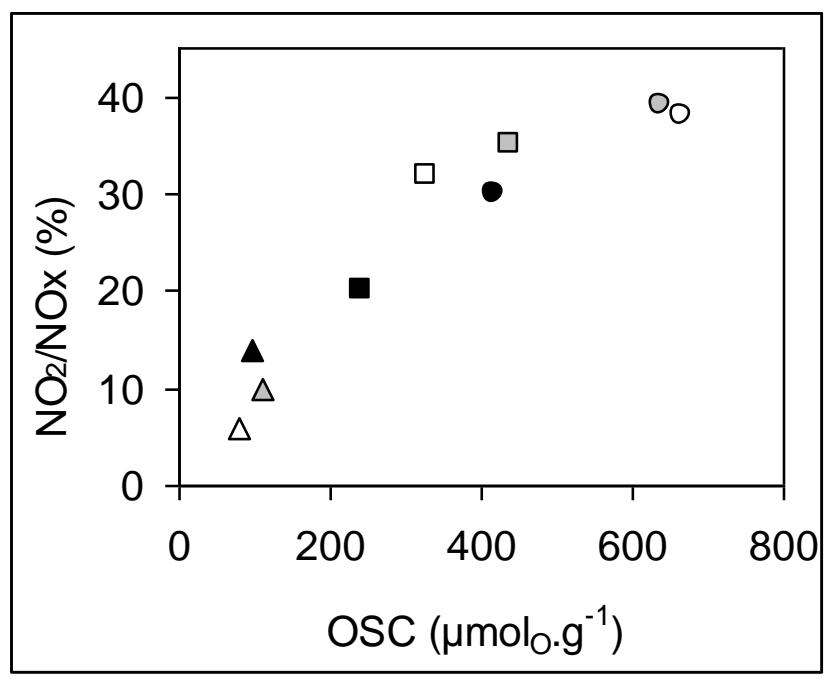

Figure 6: Reduced (R700) catalysts: relationship between the NO oxidation activity, express as the $\mathrm{NO}_{2} / \mathrm{NOx}(\%)$ ratio at saturation, and the OSC ( $\mu$ molo.g $\left.{ }^{-1}\right)$. Temperature tests: $200^{\circ} \mathrm{C}$ (triangle), $300^{\circ} \mathrm{C}$ (point) and $400^{\circ} \mathrm{C}$ (square) for $\mathrm{Pt} / \mathrm{Ce} 20$ (black symbol), Pt/Ce58 (grey symbol) and Pt/Ce70 (blank symbol). 


\subsubsection{Sulfated catalysts, aging and regeneration}

\subsubsection{Sulfated catalysts.}

Only the stabilized catalysts were submitted to sulfur poisoning, aging and regeneration. After the different treatments, the NOx storage capacities were measured only at $300^{\circ} \mathrm{C}$ with $\mathrm{H}_{2} \mathrm{O}$ and $\mathrm{CO}_{2}$ in the feed stream. The corresponding results are reported in Table 6.

Table 6: NOx storage capacities $\left(\mu \mathrm{mol} . \mathrm{g}^{-1}\right)$ at $300^{\circ} \mathrm{C}$ depending on the catalyst treatment (calculated for the first 100 seconds).

\begin{tabular}{lccccc}
\hline Catalysts & Pt/Ce100 & Pt/Ce70 & Pt/Ce58 & Pt/Ce20 & Pt/Ba/Al \\
\hline Stabilized sample $\left(700^{\circ} \mathrm{C}\right)$ & 22.8 & 16.9 & 17.4 & 16.0 & 13.8 \\
\hline Reduced sample $(\mathrm{R} 700)$ & 14.0 & 23.1 & 24.9 & 21.1 & - \\
\hline Sulfated sample (+S) & 8.3 & 5.3 & 3.6 & 3.3 & 4.6 \\
\hline$+\mathrm{S}+\mathrm{A} 800$ & 3.6 & 6.5 & 7.4 & 7.9 & 11.1 \\
\hline$+\mathrm{S}+\mathrm{R} 450$ & 5.2 & 9.8 & 9.4 & 8.0 & \\
\hline$+\mathrm{S}+\mathrm{R} 500$ & 20.1 & 21.0 & 19.6 & 16.7 & 11.9 \\
\hline$+\mathrm{S}+\mathrm{R} 550$ & 19.6 & 19.7 & 19.1 & 16.4 & 15.6 \\
\hline$+\mathrm{S}+\mathrm{A} 800+\mathrm{R} 500$ & & 12.0 & & & 12.0 \\
\hline$+\mathrm{S}+\mathrm{A} 800+\mathrm{R} 550$ & & 17.1 & & & \\
\hline
\end{tabular}

The sulfated catalysts show a dramatic decrease of their NOx storage capacities. The sulfated $\mathrm{Pt} / \mathrm{CeX}$ catalysts exhibit very low NOx storage properties, between 3.3 and $8.3 \mu \mathrm{mol} . \mathrm{g}^{-1}$, with a negative impact of the $\mathrm{Zr}$ content. The average storage loss is between $64 \%(\mathrm{Pt} / \mathrm{Ce} 100)$ and $80 \%$ ( $\mathrm{Pt} / \mathrm{Ce} 58$ and $\mathrm{Pt} / \mathrm{Ce} 20$ ). The $\mathrm{Pt} / \mathrm{Ba} / \mathrm{Al}$ catalyst is also very affected by the sulfur poisoning, with a loss of $66 \%$. Note that the $\mathrm{Pt} / \mathrm{Ba} / \mathrm{Al} \mathrm{BET}$ surface area is not affected by the sulfating treatment whereas $\mathrm{Pt} / \mathrm{Ce} 100$ and $\mathrm{Pt} / \mathrm{CeZr}$ catalysts have lost $34 \%$ and around $10 \%$, respectively. The sulfated catalysts were then characterized by $\mathrm{H}_{2}-\mathrm{TPR}$. The reduction profile of the sulfated $\mathrm{Pt} / \mathrm{Ba} / \mathrm{Al}$ catalyst (not shown but already reported in ref [30] for example) exhibits three main reduction peaks in the $400-800^{\circ} \mathrm{C}$ temperature range, all related with sulfates reduction. They were ascribed to (i) simultaneous reduction of aluminum sulfates and well dispersed barium sulfates located in platinum proximity, (ii) surface barium sulfates reduction and (iii) bulk sulfates reduction.

The TPR profiles of the sulfated Pt/CeX samples are reported in Figure 7. Compared to the stabilized ones (Figure 3), the sulfating treatment leads to both a broadening of the low temperature peak $\left(\mathrm{Ce}^{\mathrm{IV}}\right.$ reduction) and the appearance of an important hydrogen consumption 
between $300-350^{\circ} \mathrm{C}$ and $600^{\circ} \mathrm{C}$. Even if the sulfur poisoning does not significantly modify the amount of easily reducible $\mathrm{Ce}^{\mathrm{IV}}$ (Figure 4), the OSC measurements (Table 5) indicate a strong decrease of the oxygen mobility, especially at low temperature and for the higher Zr content. For the ceria-zirconia supported catalysts, the mean losses are $70 \%, 55 \%$ and $15 \%$ at $200^{\circ} \mathrm{C}$, $300^{\circ} \mathrm{C}$ and $400^{\circ} \mathrm{C}$, respectively. The effect on $\mathrm{Pt} / \mathrm{Ce} 100$ is even more pronounced, with an OSC loss of $80 \%, 75 \%$ and $40 \%$, respectively. Then, the sulfur poisoning seems to induce a limitation of the oxygen mobility mainly at the surface level. However, the NO oxidation activity at $300^{\circ} \mathrm{C}$ is nearly not affected by the sulfating treatment (Table 4). This result is rather in accordance with support reducibility deduced from the TPR experiments.

The hydrogen consumption observed at high temperature $\left(T_{r}>300-350^{\circ} \mathrm{C}\right)$ corresponds to the reduction of surface and bulk sulfates formed on ceria-zirconia support [31]. In addition, Figure 7 shows that the higher the zirconium content is, the higher the temperature of the end of the sulfate reduction is. It varies between $550^{\circ} \mathrm{C}$ for $\mathrm{Pt} / \mathrm{Ce} 100$ and $610^{\circ} \mathrm{C}$ for $\mathrm{Pt} / \mathrm{Ce} 20$. This latest sample also exhibits the broader sulfate reduction temperature range since it occurs from $350^{\circ} \mathrm{C}$. However, all these $\mathrm{Pt} / \mathrm{CeX}$ catalysts exhibit a sulfate reduction achievement at significant lower temperatures than $\mathrm{Pt} / \mathrm{Ba} / \mathrm{Al}$ [30], the improvement being between $190^{\circ} \mathrm{C}$ and $250^{\circ} \mathrm{C}$.

The integration of the $\mathrm{H}_{2}$ consumption corresponding to the sulfate reduction allows the evaluation of the sulphur content (Table 7), assuming a $\mathrm{H}_{2} / \mathrm{SO}_{4}{ }^{2-}$ ratio of 4 for the sulfate reduction $\left(\mathrm{X}-\mathrm{SO}_{4}+4 \mathrm{H}_{2} \rightarrow \mathrm{X}-\mathrm{S}+4 \mathrm{H}_{2} \mathrm{O}\right.$ and/or $\mathrm{X}-\mathrm{SO}_{4}+4 \mathrm{H}_{2} \rightarrow \mathrm{X}-\mathrm{O}+\mathrm{H}_{2} \mathrm{~S}+3 \mathrm{H}_{2} \mathrm{O}$,). For the $\mathrm{Pt} / \mathrm{CeX}$ catalysts, the amount of sulfur injected in the gas flow during the sulfating treatment (2 wt $\%$ ) is not totally deposited. It varies with the increase of the $\mathrm{Zr}$ content, from $1.24 \%$ for $\mathrm{PtCe} 100$ to $1.41 \%$ for $\mathrm{Pt} / \mathrm{Ce} 20$. For comparison, the sulfur content on the $\mathrm{Pt} / \mathrm{Ba} / \mathrm{Al}$ catalyst reaches $1.56 \%$. These sulfur rates are consistent with results obtained by the pyrolysis technique

Table 7: Sulfur content (wt \%) and sulfur elimination rate (\%, between bracket) deduced from the TPR experiments, depending on the applied treatments. Sulfated sample $(+\mathrm{S})$, sulfated and aged sample at $800^{\circ} \mathrm{C}(+\mathrm{S}+\mathrm{A} 800)$; sulfated and regenerated sample at $450^{\circ} \mathrm{C}(+\mathrm{S}+\mathrm{R} 450)$, $550^{\circ} \mathrm{C}(+\mathrm{S}+\mathrm{R} 500)$ and $550^{\circ} \mathrm{C}(+\mathrm{S}+\mathrm{R} 500)$, sulfated, aged and regenerated sample $(+\mathrm{S}+\mathrm{A} 800+\mathrm{R} 550)$

\begin{tabular}{lccccc}
\hline Catalysts & $\mathrm{Pt} / \mathrm{Ce} 100$ & $\mathrm{Pt} / \mathrm{Ce} 70$ & $\mathrm{Pt} / \mathrm{Ce} 58$ & $\mathrm{Pt} / \mathrm{Ce} 20$ & $\mathrm{Pt} / \mathrm{Ba} / \mathrm{Al}$ \\
\hline$+\mathrm{S}$ & 1.24 & 1.26 & 1.32 & 1.41 & 1.56 \\
\hline$+\mathrm{S}+\mathrm{A} 800$ & 0.10 & 0.19 & 0.21 & 0.22 & 1.42 \\
(sulfur elimination rate (\%)) & $(92 \%)$ & $(85 \%)$ & $(84 \%)$ & $(84 \%)$ & $(9 \%)$ \\
\hline$+\mathrm{S}+\mathrm{R} 450$ & 0.22 & 0.50 & 0.51 & 0.46 & - \\
$($ sulfur elimination rate (\%)) & $(82 \%)$ & $(60 \%)$ & $(62 \%)$ & $(68 \%)$ & - \\
\hline$+\mathrm{S}+\mathrm{R} 500$ & 0.15 & 0.15 & 0.11 & 0.05 & 0.76 \\
(sulfur elimination rate (\%)) & $(88 \%)$ & $(88 \%)$ & $(92 \%)$ & $(96 \%)$ & $(51 \%)$ \\
\hline +S+R550 & 0.11 & 0.09 & 0.07 & 0.01 & 0.69 \\
(sulfur elimination rate (\%)) & $(91 \%)$ & $(93 \%)$ & $(95 \%)$ & $(99 \%)$ & $(56 \%)$ \\
\hline$+\mathrm{S}+$ A800+R550 & & $\approx 0$ & & & 1.37 \\
$($ sulfur elimination rate (\%)) & - & $(100 \%)$ & - & - & $(12 \%)$ \\
\hline
\end{tabular}




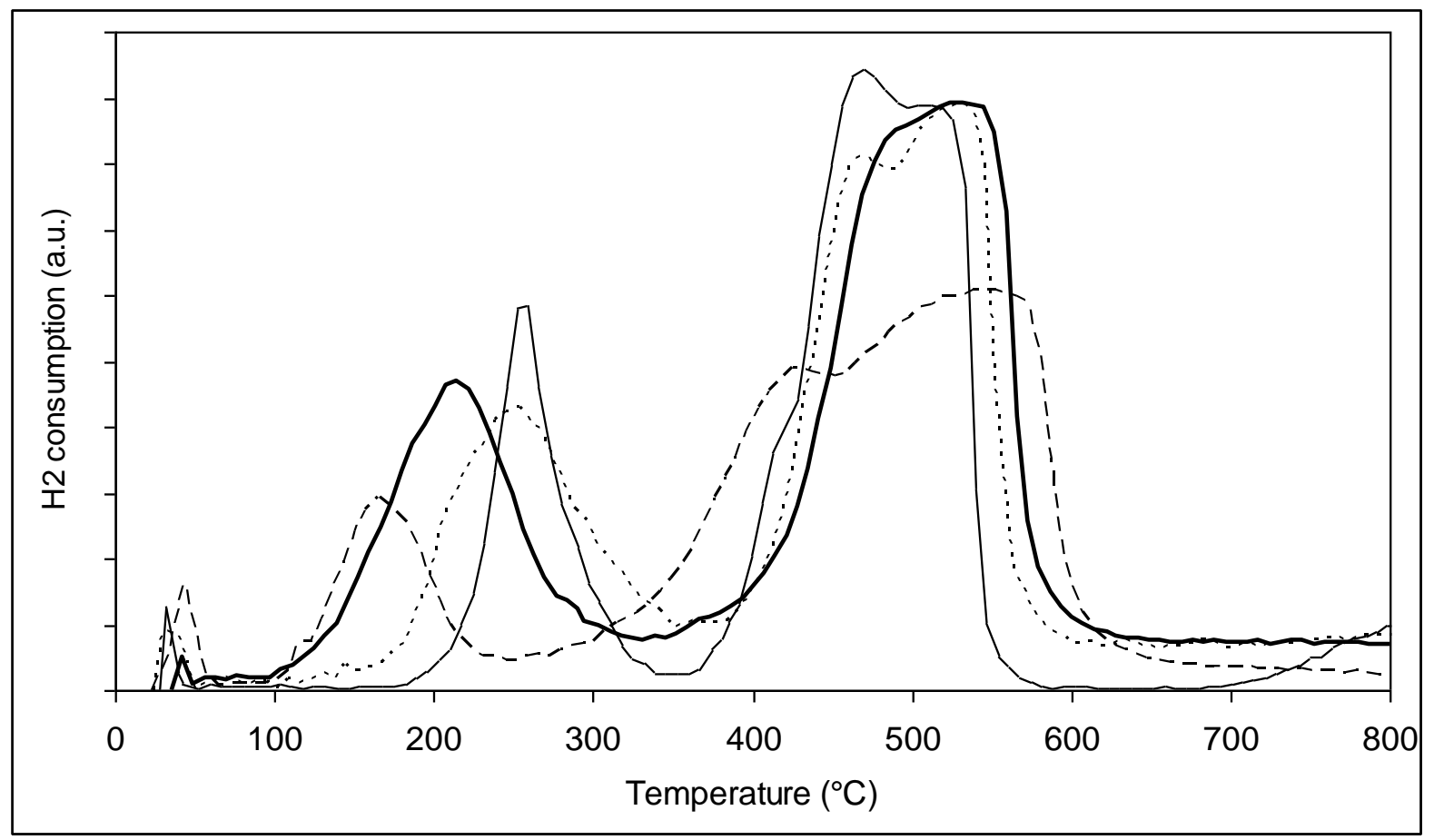

Figure 7: TPR profiles of the sulfated Pt/CeX catalysts: Pt/Ce100 (-), Pt/Ce70 ( $\cdots), \mathrm{Pt} / \mathrm{Ce} 58$ (一) and $\mathrm{Pt} / \mathrm{Ce} 20$ (---).

\subsubsection{Thermal aging of the sulfated catalysts}

The aging at $800^{\circ} \mathrm{C}$ of the sulfated ceria-zirconia supported catalysts leads to a small recovery of the NOx storage capacity at $300^{\circ} \mathrm{C}$ (Table 6), even though the specific surface area show a significant decrease, near 20\% (Table 2). On the contrary, the Pt/Ce100 catalyst decreases again, which can be attributed to the strong surface area loss compared to the sulfated sample (-70\%). Compared to the stabilized samples, the NO oxidation rate of the $\mathrm{Pt} / \mathrm{CeX}$ catalysts, expressed as the $\mathrm{NO}_{2} / \mathrm{NOx}$ ratio at saturation, is lower (Table 4), which can be attributed to a platinum sintering. In the same time, nearly $85 \%$ of the deposited sulfur is eliminated by the aging treatment at $800^{\circ} \mathrm{C}$ on the ceria-zirconia catalysts, only $0.19-0.22 \% \mathrm{~S}$ remains (Table 7). The sulfur elimination reaches $92 \%$ on $\mathrm{Pt} / \mathrm{Ce} 100,0.10 \% \mathrm{~S}$ remains.

The sulfated $\mathrm{Pt} / \mathrm{Ba} / \mathrm{Al}$ catalyst is also favorably affected by the aging treatment at $800^{\circ} \mathrm{C}$. Its surface area is unchanged and a partial recovery of the NOx storage capacity is obtained $(80 \%$ of the initial value is restored). After the aging treatment, its NOx storage capacity is significantly higher than the $\mathrm{Pt} / \mathrm{CeX}$ catalysts. However, the sulfur elimination due to the aging treatment is very small: $9 \%$ (Table 7), indicating that only the surface is cleaned.

\subsubsection{Sulfates stability in reducing atmosphere.}

It was previously observed for $\mathrm{Pt} / \mathrm{Ba} / \mathrm{Al}$ samples that a sulfated catalyst reduced at $800^{\circ} \mathrm{C}$ under $1 \% \mathrm{H}_{2} / \mathrm{Ar}$ (TPR protocol) and reoxidized at $400^{\circ} \mathrm{C}$ still exhibits a $\mathrm{H}_{2}$ consumption corresponding to sulfates reduction during the consecutive TPR. Indeed, during the first TPR run, a part of the sulfates can be reduced in sulfide [5]. Then, the stored sulfur was only partially eliminated, even though all sulfates were reduced at the end of the test, i.e. at $800^{\circ} \mathrm{C}$. Then, similar experiments were carried out on the $\mathrm{Pt} / \mathrm{CeX}$ samples. Representative results, obtained 
with the Pt/Ce20 catalyst, are plotted in Figure 8 . This graph clearly shows that a part of the sulfur is not eliminated after the first TPR treatment, event if the sulfate reduction is achieved. Around $0.36 \mathrm{wt} \% \mathrm{~S}$ remains, probably as sulfides, compared to $1.41 \mathrm{wt} \%$ initially. A weak stabilization of the re-formed sulfates is observed, but the reduction is achieved at $600^{\circ} \mathrm{C}$. It can be also observed that the first reduction treatment of the sulfated sample induces the same $\mathrm{Ce}^{\mathrm{IV}}$ reduction improvement as previously observed for the un-sulfated $\mathrm{Pt} / \mathrm{CeX}$ samples. After a first reduction, the $\mathrm{H}_{2}$ consumption corresponding to the easily reducible $\mathrm{Ce}^{\mathrm{IV}}$ is shifted to lower temperature with a maximum at $50^{\circ} \mathrm{C}$, without any change of the corresponding $\mathrm{H}_{2}$ consumption (around to $420 \mu \mathrm{mol}_{\mathrm{H} 2} \cdot \mathrm{g}^{-1}$ ).

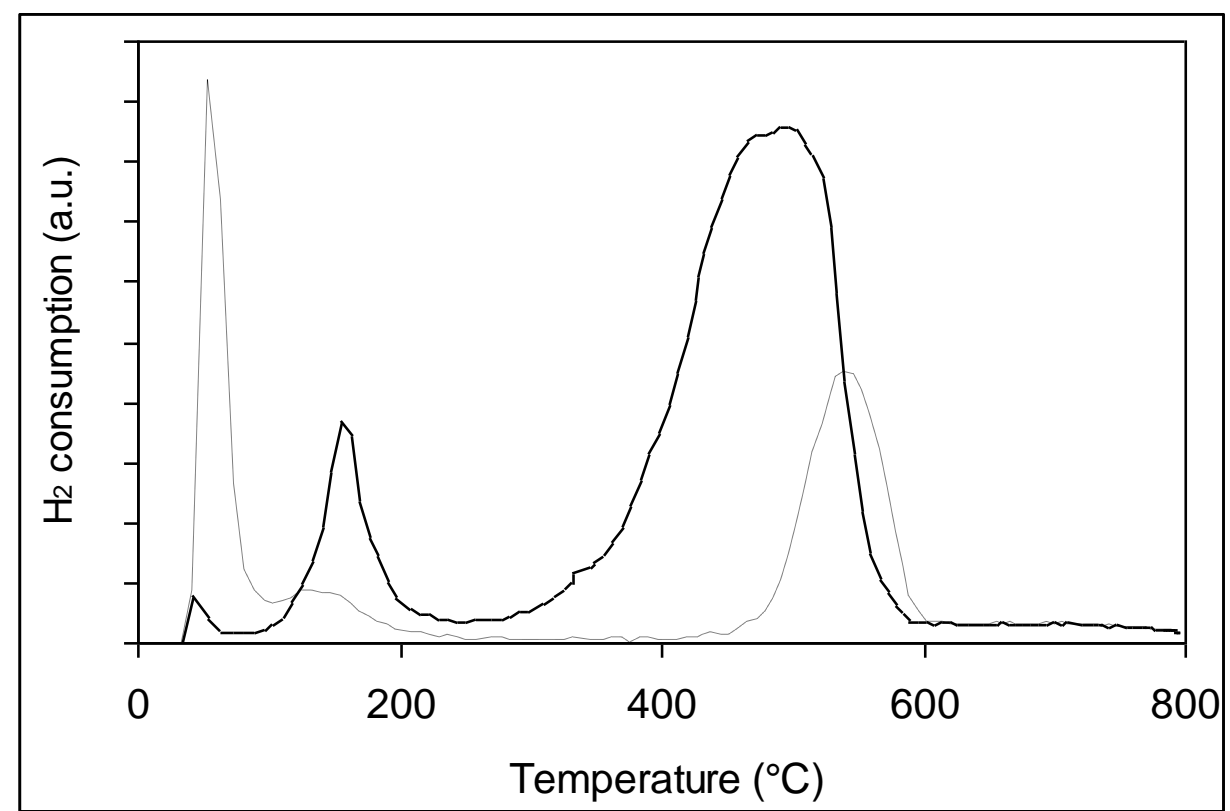

Figure 8: TPR profiles of Pt/Ce20 + S (-) and Pt/Ce20 + S after the first TPR until $800^{\circ} \mathrm{C}$ and reoxidized at $300^{\circ} \mathrm{C}(---)$.

To improve the sulfur elimination, a reducing treatment with a mixture containing $2.5 \% \mathrm{H}_{2}$, $10 \% \mathrm{CO}_{2}, 10 \% \mathrm{H}_{2} \mathrm{O}$ and $\mathrm{N}_{2}$ was found to be appropriate [5]. The optimum regeneration temperature depends on the catalyst composition, with a compromise between the sulfur elimination rate and the possible thermal aging. For instance, for a $0.5 \mathrm{~h}$ treatment, $650^{\circ} \mathrm{C}$ was found to be optimal for a $\mathrm{Pt} / 20 \mathrm{wt} \% \mathrm{BaO} / \mathrm{Al}_{2} \mathrm{O}_{3}$ catalyst [5] and $550{ }^{\circ} \mathrm{C}$ is enough for $\mathrm{Pt} / 10 \mathrm{wt} \% \mathrm{BaO} / \mathrm{Al}_{2} \mathrm{O}_{3}$ or $\mathrm{Pt} / 10 \mathrm{wt} \% \mathrm{BaO} / \mathrm{Ce}_{0.7} \mathrm{Zr}_{0.3} \mathrm{O}_{2}$ [19]. In this study, three regeneration temperatures were tested: $550^{\circ} \mathrm{C}, 500^{\circ} \mathrm{C}$ and $450^{\circ} \mathrm{C}$.

After regeneration at $550^{\circ} \mathrm{C}$, from $90 \%$ to $99 \%$ of the initially deposited sulfur on the $\mathrm{Pt} / \mathrm{CeX}$ catalysts is removed (Table 7). The elimination rate increases with the zirconium content. This elimination rate is still very high after a regeneration treatment at $500^{\circ} \mathrm{C}$, between $88 \%$ and $96 \%$. However, it decreases to $60 \%-68 \%$ at $450^{\circ} \mathrm{C}$ for the ceria-zirconia supported catalysts, whereas the sulfur elimination reaches $82 \%$ for Pt/Ce100. The corresponding TPR characterizations are presented in Figure 9 for $\mathrm{Pt} / \mathrm{Ce} 100$ and $\mathrm{Pt} / \mathrm{Ce} 20$. 

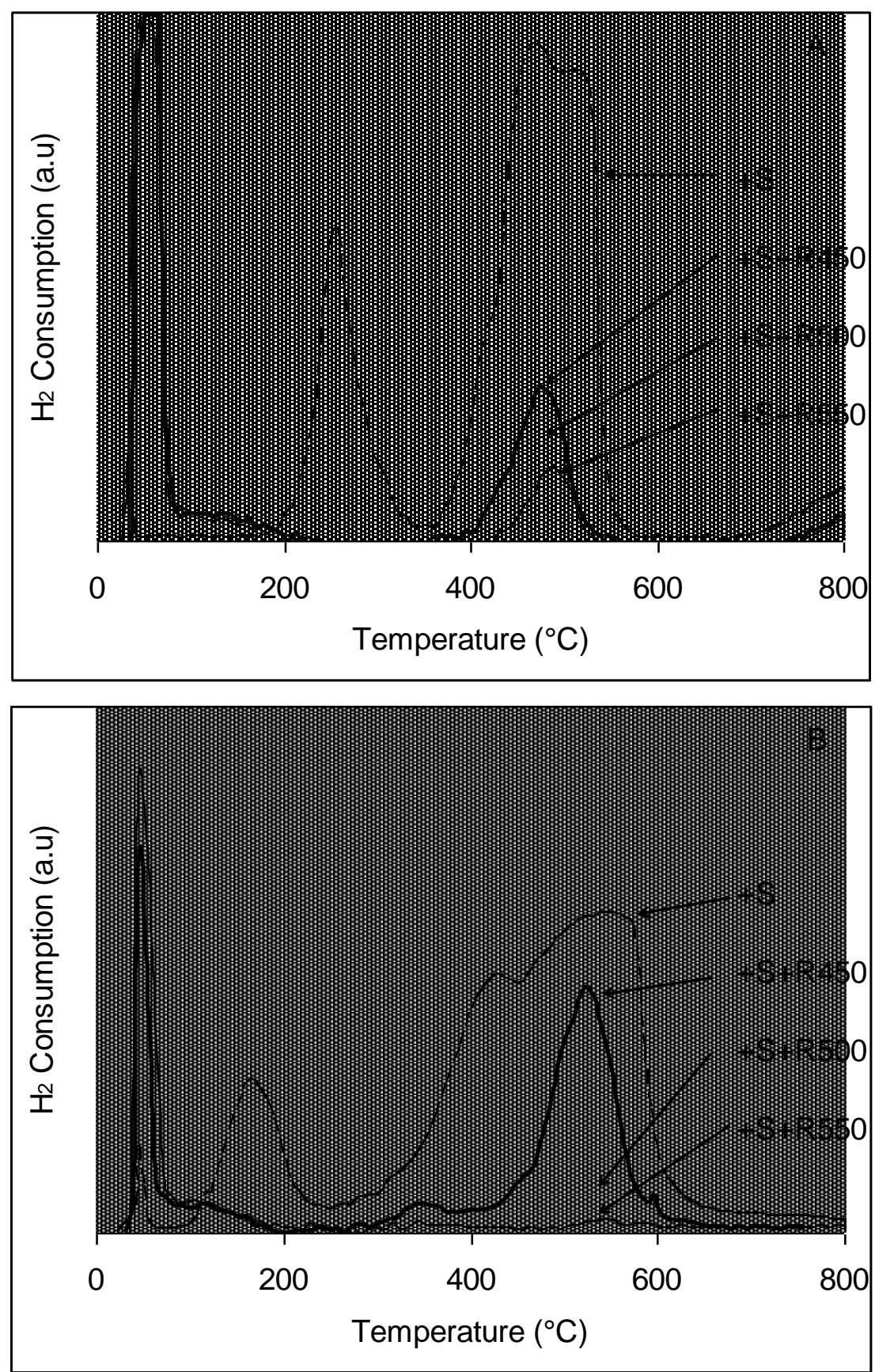

Figure 9: TPR profiles of A) Pt/Ce100 and B) Pt/Ce20. Sulfated sample (--), after regeneration at $450^{\circ} \mathrm{C}+\mathrm{S}+\mathrm{R} 450(-)$, after regeneration at $500^{\circ} \mathrm{C}+\mathrm{S}+\mathrm{R} 500($ (ax) $)$, after regeneration at $450^{\circ} \mathrm{C}$ $+\mathrm{S}+\mathrm{R} 550(-)$.

Compared to the $\mathrm{Pt} / \mathrm{CeX}$ catalysts, the sulfur elimination on $\mathrm{Pt} / \mathrm{Ba} / \mathrm{Al}$ is significantly lower. Only half of the initial deposited sulfur is removed at $500^{\circ} \mathrm{C}$, and the rate increases to only $56 \%$ at $550^{\circ} \mathrm{C}$ (Table 7).

Compared to the stabilized catalysts, the NOx storage capacity at $300^{\circ} \mathrm{C}$ is at least fully recovered after the regeneration treatment at $550^{\circ} \mathrm{C}$ for all the catalysts, except $\mathrm{Pt} / \mathrm{Ce} 100$ (Table 6 ). The slight improvements on the ceria-zirconia supported catalysts can be attributed to the reducing treatment, as seen previously for the reduced samples (R700). Indeed, Figure 9 shows 
that the improvement of the cerium reducibility is also obtained after the regeneration treatment in lean atmosphere and data reported Table 4 show that the $\mathrm{NO}_{2} / \mathrm{NOx}$ ratio is improved too. The influence of a reducing treatment can also explain the Pt/Ce100 decline since the surface area of this sample is very sensitive to sintering under reducing atmosphere (Table 2). The decrease of the regeneration temperature down to $500^{\circ} \mathrm{C}$ leads to similar results for $\mathrm{Pt} / \mathrm{CeX}$ catalysts (Table 6). On the contrary, this temperature is not sufficient for $\mathrm{Pt} / \mathrm{Ba} / \mathrm{Al}$, only $86 \%$ of the initial NOx storage capacity is recovered. For Pt/CeX catalysts, it was then interesting to test lower regeneration temperature: $450^{\circ} \mathrm{C}$ for $0.5 \mathrm{~h}$. Measurements show that this condition is not severe enough to totally restore the initial NOx storage capacities. Near half of the initial capacities were then obtained for ceria-zirconia supported samples.

Some additional tests were performed with $\mathrm{Pt} / \mathrm{Ba} / \mathrm{Al}$ and $\mathrm{Pt} / \mathrm{Ce} 70$ (selected as $\mathrm{Pt} / \mathrm{CeX}$ sample) to evaluate the regeneration of sulfated and consecutively aged samples $(+\mathrm{S}+\mathrm{A} 800)$. After regeneration at $550^{\circ} \mathrm{C}$, the sulfated and aged $\mathrm{Pt} / \mathrm{Ba} / \mathrm{Al}$ catalyst exhibits a good recovery of the NOx storage capacity, at $12 \mu \mathrm{mol} . \mathrm{g}^{-1}$, i.e. $87 \%$ of the initial value (Table 6). However, the aging treatment also induces a stabilization of the sulfates since only $12 \%$ of the initial deposited sulfur is eliminated, whereas $9 \%$ was already eliminated after aging (Table 7). On the contrary, the sulfates are fully eliminated on the $\mathrm{Pt} / \mathrm{Ce} 70$ catalyst after aging and regeneration at $550^{\circ} \mathrm{C}$ or $500^{\circ} \mathrm{C}$. If the NOx storage capacity is not fully recovered after regeneration at $500^{\circ} \mathrm{C}$, reducing treatment at $550^{\circ} \mathrm{C}$ leads to a total regeneration (Table 6).

\subsection{NOx conversion in cycling conditions}

The NOx removal efficiency was measured in cycling rich/lean condition. Since a reducing treatment influenced the NOx storage properties of the ceria-zirconia supported catalysts, only the pre-reduced samples was studied. For comparison, the $\mathrm{Pt} / \mathrm{Ba} / \mathrm{Al}$ catalyst was also tested. Whatever the used conditions and catalyst, no significant amount of $\mathrm{N}_{2} \mathrm{O}$ was observed. Typical recorded curves, obtained with $\mathrm{Pt} / \mathrm{Ba} / \mathrm{Al}$ at $400^{\circ} \mathrm{C}$, are presented Figure 10 . The results obtained with $3 \% \mathrm{H}_{2}$ in the rich periods are reported in Figure 11A.

At $200^{\circ} \mathrm{C}$, the $\mathrm{Pt} / \mathrm{Ba} / \mathrm{Al}$ reference catalyst exhibits $66 \%$ of NOx removal efficiency. At this temperature, only $34 \%$ of the introduced hydrogen reacts. In the same time, the ammonia formation is significant, corresponding to a selectivity of $28 \%$. The increase of the temperature test to $300^{\circ} \mathrm{C}$ leads to an improvement of the NOx conversion up to $78 \%$. As the NOx storage capacities are similar at $200^{\circ} \mathrm{C}$ and $300^{\circ} \mathrm{C}$ for this sample (Table 3), it means that the reducing step is improved, in accordance with the increase of the hydrogen consumption to $41 \%$. However, the ammonia selectivity remains nearly unchanged, at $30 \%$. At $400^{\circ} \mathrm{C}$, the $\mathrm{NOx}$ conversion does not increase anymore, but both hydrogen consumption and ammonia selectivity increase, at $52 \%$ and $36 \%$, respectively.

With $\mathrm{Pt} / \mathrm{Ba} / \mathrm{Al}$, the hydrogen concentration is not the limiting parameter since less than half of the injected $\mathrm{H}_{2}$ is converted with $3 \% \mathrm{H}_{2}$ in the rich pulse. Then, as expected, increasing the $\mathrm{H}_{2}$ concentration to $6 \%$ in the rich pulse does not significantly affect the behavior of $\mathrm{Pt} / \mathrm{Ba} / \mathrm{Al}$ (Figure 11B). Re-calculations of the NOx storage capacities during the first $30 \mathrm{~s}$ show that around $80 \%-85 \%$ of the inlet NOx is stored. Then, it partially explains the limitation of the NOx conversion. In addition, some NOx desorption can occur without reduction at the beginning of the rich pulses $[32,33]$. 
For the ceria-zirconia supported catalyst, the NOx conversions with $3 \% \mathrm{H}_{2}$ in the rich pulses are between $38 \%$ and $48 \%$ at $200^{\circ} \mathrm{C}$ and the $\mathrm{H}_{2}$ consumption rates reach $77 \%-100 \%$, depending on the support composition (Figure 11A).

Compared to $\mathrm{Pt} / \mathrm{Ba} / \mathrm{Al}$, these NOx conversion rates are significantly lower even if the NOx storage capacities are quite similar. On the contrary, the $\mathrm{H}_{2}$ consumption rates are higher (34\% for $\mathrm{Pt} / \mathrm{Ba} / \mathrm{Al}$ ): a large part of the introduced hydrogen is then consumed by the reduction of the ceria-zirconia supports.

Concerning the ceria-zirconia supported catalysts, the lower conversion rate is obtained with $\mathrm{Pt} / \mathrm{Ce} 58$, whereas this catalyst exhibits the higher NOx storage capacity (Table 3). Then in this case, the NOx conversion is not directly related with the NOx storage capacity. In the same time, the introduced hydrogen was totally converted for Pt/Ce58 whereas $92 \%$ and $77 \%$ were consumed with Pt/Ce70 and Pt/Ce20, respectively. These values are related with the kinetics of reduction (OSC) and to the amount of reducible species (TPR). With Pt/Ce58, there is not enough hydrogen to reduce both support and stored NOx. It is important to note that compared with $\mathrm{Pt} / \mathrm{Ba} / \mathrm{Al}$, the $\mathrm{N}_{2}$ selectivity is significantly improved with the ceria-zirconia supported catalysts. At $200^{\circ} \mathrm{C}$, ammonia formation was observed only with $\mathrm{Pt} / \mathrm{Ce} 20$, corresponding to $10 \%$ selectivity.

Increasing the temperature test to $300^{\circ} \mathrm{C}$ leads to a significant increase of the NOx removal efficiency at $62-66 \%$, whereas the corresponding NOx storage capacities are nearly the same at $200^{\circ} \mathrm{C}$ and $300^{\circ} \mathrm{C}$. Then, the reducing step was the limiting step at $200^{\circ} \mathrm{C}$. Furthermore, the ammonia selectivity at $300^{\circ} \mathrm{C}$ becomes near nil for all the ceria-zirconia supported catalysts. Note also that the introduced hydrogen is totally converted with $\mathrm{Pt} / \mathrm{Ce} 58$ and $\mathrm{Pt} / \mathrm{Ce} 70$, but only $85 \%$ with $\mathrm{Pt} / \mathrm{Ce} 20$ which exhibits the lower OSC.

The increasing of the temperature test to $400^{\circ} \mathrm{C}$ leads only to a small decrease of the NOx conversion. This can be attributed to the small decrease of the NOx storage capacity at this temperature. Some hydrogen still remains at $400^{\circ} \mathrm{C}$ with $\mathrm{Pt} / \mathrm{Ce} 20$, even if its conversion rate increases to $94 \%$.

As the hydrogen consumption can reach $100 \%$ with the ceria-zirconia supported catalysts, further investigations were carried out increasing the $\mathrm{H}_{2}$ concentration in the rich pulse to $6 \%$. At $200^{\circ} \mathrm{C}$, the hydrogen conversion rate reaches $92-93 \%$ for Pt/Ce58 and $\mathrm{Pt} / \mathrm{Ce} 70$ and only $46 \%$ for $\mathrm{Pt} / \mathrm{Ce} 20$ (lower OSC). Comparing with $3 \% \mathrm{H}_{2}$, the $\mathrm{NOx}$ conversion rate is just a little improved, and more interestingly, it varies neither with the OSC nor the NOx storage capacity, but with the cerium content (from $47 \%$ for $\mathrm{Pt} / \mathrm{Ce} 20$ to $58 \%$ for Pt/Ce70). Simultaneously, the ammonia production decreases with the cerium content, leading to $\mathrm{NH}_{3}$ selectivity of $16 \%, 8 \%$ and $3 \%$ for $\mathrm{Pt} / \mathrm{Ce} 20, \mathrm{Pt} / \mathrm{Ce} 58$ and $\mathrm{Pt} / \mathrm{Ce} 70$, respectively.

The increase of the temperature test to $300^{\circ} \mathrm{C}$ leads to an improvement of the NOx conversion, as well as with $3 \% \mathrm{H}_{2}$. The results are quite similar at $400^{\circ} \mathrm{C}$, always with a small improvement with the cerium content. At $300^{\circ} \mathrm{C}$ and $400^{\circ} \mathrm{C}$, at least $90 \%$ the hydrogen is converted and the ammonia selectivity tends to become nil for the three ceria-zirconia supported catalysts.

Finally the NOx conversion rate obtained with the ceria-zirconia supported catalysts are lower than those obtained with $\mathrm{Pt} / \mathrm{Ba} / \mathrm{Al}$. However, the ammonia selectivity is significantly decreased 
with the ceria-zirconia mixed oxides. With $3 \% \mathrm{H}_{2}$ in the rich pulse, near no ammonia was observed, excepted with $\mathrm{Pt} / \mathrm{Ce} 20$ at $200{ }^{\circ} \mathrm{C}$ (10\% $\mathrm{NH}_{3}$ selectivity). In opposition, the $\mathrm{NH}_{3}$ selectivity reaches $28 \%-37 \%$ with $\mathrm{Pt} / \mathrm{Ba} / \mathrm{Al}$, depending on the temperature test.

Whatever the temperature test, with $3 \% \mathrm{H}_{2}$ in the rich pulse, the lower NOx conversion is obtained with $\mathrm{Pt} / \mathrm{Ce} 58$ and the introduced $\mathrm{H}_{2}$ is then fully converted. This catalyst also exhibits the higher oxygen mobility/storage capacity.

When $6 \% \mathrm{H}_{2}$ is used in the rich pulse, the NOx conversion rate increases with the cerium concentration in the mixed oxide (relationship neither with the NOx storage capacity nor the OSC). Simultaneously, it also confirms that the ammonia selectivity decreases with the increase of the cerium content, even in case the introduced $\mathrm{H}_{2}$ is not totally converted.
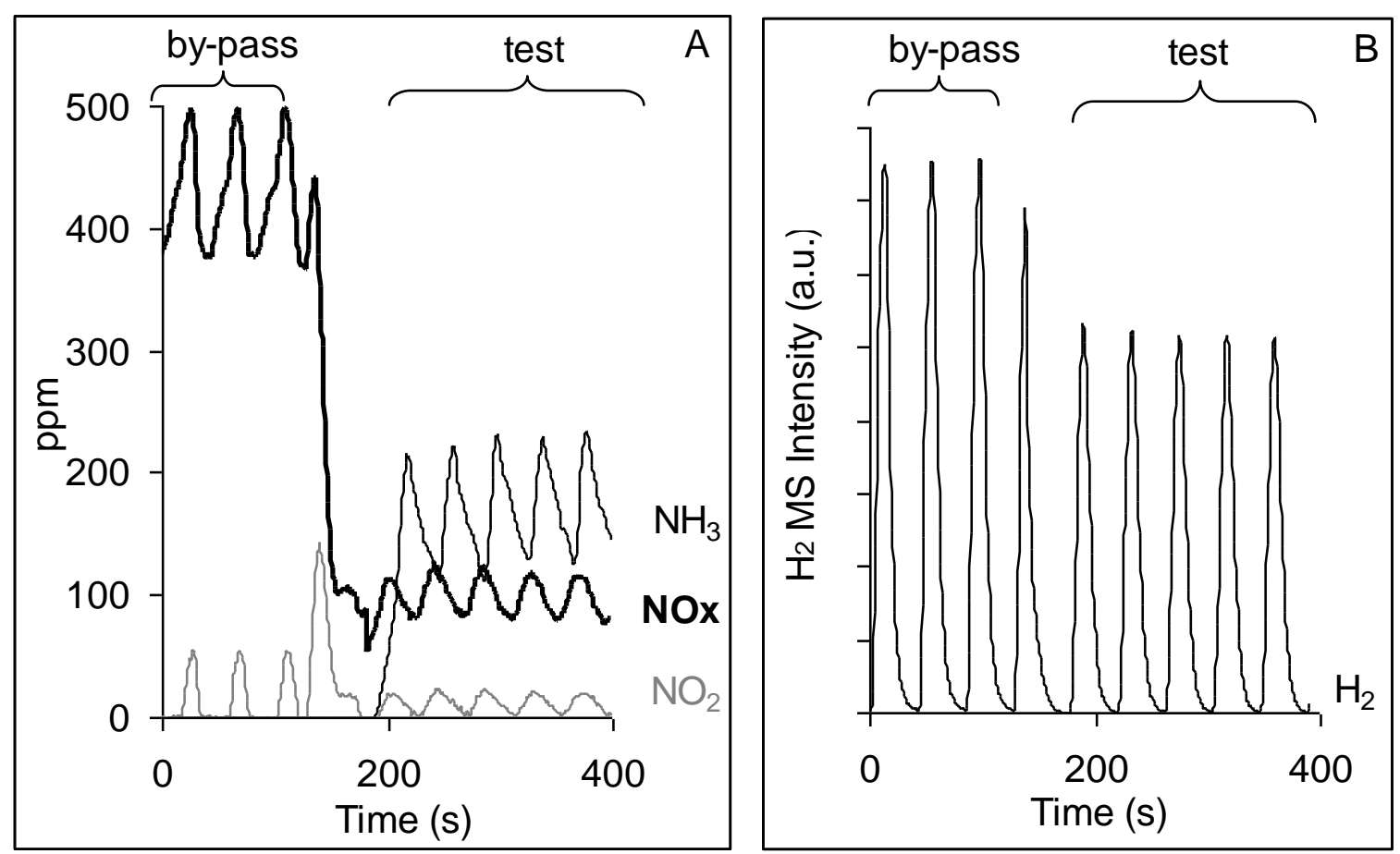

Figure 10: Typical storage-reduction experimental curves. Results obtained at $400^{\circ} \mathrm{C}$ with stabilized $\mathrm{Pt} / \mathrm{Ba} / \mathrm{Al}$ with $6 \% \mathrm{H}_{2}$ in the rich pulse. A) $\mathrm{NOx}, \mathrm{NO}_{2}$ (chemiluminescence) and $\mathrm{NH}_{3}$ concentrations (FTIR multigas analyzer), B) $\mathrm{H}_{2}$ signal (mass spectrometer). 

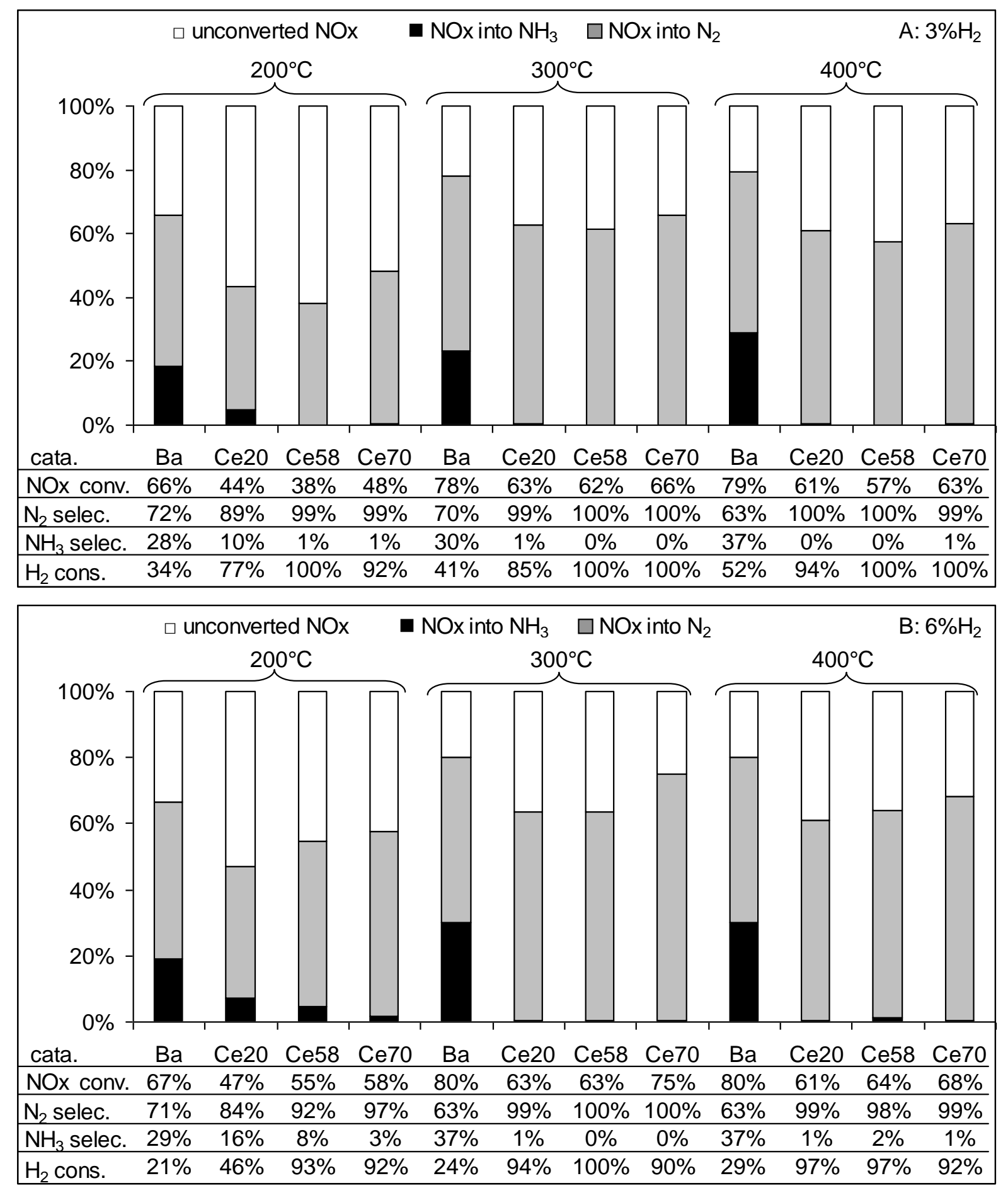

Figure 11: NOx conversion in cycling condition (60s lean, $3 \mathrm{~s}$ rich). NOx conversion into $\mathrm{N}_{2}$ ( 口), $\mathrm{NOx}$ conversion into $\mathrm{NH}_{3}(\mathbf{\square})$, corresponding selectivity and $\mathrm{H}_{2}$ consumption rate. a) $3 \% \mathrm{H}_{2}$ in the rich pulse; $b): 6 \% \mathrm{H}_{2}$ in the rich pulse.

$\mathrm{Ba}, \mathrm{Ce} 20, \mathrm{Ce} 58$ and $\mathrm{Ce} 70$ are $\mathrm{Pt} / \mathrm{Ba} / \mathrm{Al}, \mathrm{Pt} / \mathrm{Ce} 20, \mathrm{Pt} / \mathrm{Ce} 58$ and $\mathrm{Pt} / \mathrm{Ce} 70$, respectively. 


\section{Conclusion:}

The behaviors of the ceria-zirconia supported catalysts are quite similar whatever their composition. Their NOx storage capacities are rather higher than the $\mathrm{Pt} / \mathrm{Ba} / \mathrm{Al}$ model catalyst, with an optimal storage at $200^{\circ} \mathrm{C}$ versus $400^{\circ} \mathrm{C}$ for $\mathrm{Pt} / \mathrm{Ba} / \mathrm{Al}$. The ceria-zirconia supported catalysts are sensitive to a reducing pre-treatment, which leads to an increase of (i) the cerium reducibility/oxygen mobility, (ii) the NO oxidation rate and (iii) the NOx storage capacity at 300 and $400^{\circ} \mathrm{C}$. The sulfating treatment leads to a dramatic decrease of the NOx storage capacity for all catalysts, the decrease being more pronounced for the $\mathrm{Zr}$-rich samples. $\mathrm{H}_{2}-\mathrm{TPR}$ experiments show that the sulfates amount and their stability tend to increase with the $\mathrm{Zr}$ content. However, these sulfates remain significantly less stable compared with $\mathrm{Pt} / \mathrm{Ba} / \mathrm{Al}$. The sulfur elimination rates in rich mixture at $550^{\circ} \mathrm{C}$ are higher than $90 \%$ with the ceria-zirconia supported catalysts versus $56 \%$ with $\mathrm{Pt} / \mathrm{Ba} / \mathrm{Al}$. The NOx storage capacities are recovered after sulfur regeneration at $500^{\circ} \mathrm{C}$ only for the ceria-zirconia supported catalysts.

The ceria-zirconia supported catalysts are able to convert NOx in lean-rich cycling condition. Compared with $\mathrm{Pt} / \mathrm{Ba} / \mathrm{Al}$, the NOx conversions are a little lowered. However, the ammonia selectivity is significantly decreased with the ceria-zirconia mixed oxides. With $3 \% \mathrm{H}_{2}$ in the rich pulses, it reaches $28 \%-37 \%$ with $\mathrm{Pt} / \mathrm{Ba} / \mathrm{Al}$, depending on the temperature test and, near no ammonia was observed, except with $\mathrm{Pt} / \mathrm{Ce} 20$ at $200^{\circ} \mathrm{C}\left(10 \% \mathrm{NH}_{3}\right.$ selectivity). With $6 \% \mathrm{H}_{2}$ in the rich pulses, it was confirmed that the ammonia selectivity decreases with the increase of the cerium content.

Finally, despite a high OSC leading to a reducer over-consumption, the ceria rich sample seems to be the more interesting one. It presents good properties toward NOx storage/sulur regeneration and nearly no $\mathrm{NH}_{3}$ formation during the $\mathrm{NOx}$ conversion in lean-rich cycling condition.

\section{References}

[1] W. S. Epling, L. E. Campbell, A. Yezeerets, N. W. Currier, J. E. Parks II, Catal. Rev. 46 (2004) 163.

[2] T. Kobayashi, T. Yamada, K. Kayano, Society of Automotive Engineers, Inc. Technical Papers, 970745

[3] S. Matsumoto, Cattech, Vol.4, no.2, 2000

[4] A. Amberntsson, M. Skoglundh, S. Ljungström, E. Fridell, Journal of Catalysis 217 (2003) 253

[5] S. Elbouazzaoui, E.C. Corbos, X. Courtois, P. Marecot, D. Duprez, Appl. Catal. B 61 (2005) 236

[6] T. Szailer, J.H. Kwak, D.H. Kim, J. Szanyi, C. Wang, C.H.F. Peden, Catal. Today 114 (2006) 86-93

[7] H.Y. Huang, R.Q. Long, R.T. Yang, Appl. Catal. B 33 (2001) 127

[8] K. Yamazaki, T. Suzuki, N. Takahashi, K. Yokota, M. Sugiura, Appl. Catal. B 30 (2001) 459

[9] S. Hodjati, C. Petit, V. Pitchon, A. Kiennemann, Appl. Catal. B 30 (2001) 247

[10] F. Basile, G. Fornasari, A. Grimandi, M. Livi, A. Vaccari, Appl. Catal. B 69 (2006) 58

[11] M. Eberhardt, R. Riedel, U. Göbel, J. Theis, E. S. Lox, Topics Catal. 30/31 (2004) 135. 
[12] M. Casapu, J.D. Grunwaldt, M. Maciejewski, M. Wittrock, U. Gobel, A. Baiker, Appl. Catal. B 63 (2006) 232

[13] L. F. Liotta, A. Macaluso, G. E. Arena, M. Livi, G. Centi, G. Deganello, Catal. Today 75 (2002) 439.

[14] .H. Kwak, D.H. Kim, J. Szanyi, C.H.F. Peden, Appl. Catal. B 84 (2008) 545-551

[15] S. Philipp, A. Drochner, J. Kunert, H. Vogel, J. Theis, E. S. Lox, Topics Catal. 30/31 (2004) 235.

[16] P. Svedberg, E. Jobson, S. Erkfeldt, B. Andersson, M. Larsson, M. Skoglundh, Topics Catal. 30 (2004) 199

[17] H.Y. Lin, C.J. Wu, Y.W. Chen, C.H. Lee, Ind. Eng. Chem. Res. 45 (2006) 134.

[18] T. Nakatsuji, J. Ruotoistenmäki, V. Komppa, Y. Tanaka, T. Uekusa, Appl. Catal. B 38 (2002) 101.

[19] E.C. Corbos, S. Elbouazzaoui, X. Courtois, N. Bion, P. Marecot, D. Duprez, Topics Catal. 42-43 (2007) 9

[20] M. Machida, D. Kurogi, T. Kijima, Chem. Mater 12 (2000) 3165

[21] H. Mahzoul, L. Limousy, J.F. Brilhac, P. Gilot, J. of Analytical and Applied Pyrolysis 56 (2000) 179

[22] E.C. Corbos, X. Courtois, F. Can, P. Marecot, D. Duprez, Applied Catalysis B:

Environmental 84 (2008) 514-523

[23] E.C. Corbos, X. Courtois, N. Bion, P. Marecot, D. Duprez, Appl. Catal. B 76 (2007) 357

[24] S. Kacimi, J. Barbier Jr., R. Taha, D. Duprez, Catal. Lett. 22 (1993) 343

[25] H. Shinjoh, M. Hatanaka, Y. Nagai, T. Tanabe, N. Takahashi, T. Yoshida, Y. Miyake, Top Catal DOI 10.1007/s11244-009-9371-5

[26] V. Perrichon, L. Retailleau, P. Bazin, M. Daturi, J.C. Lavalley, Appl. Catal. A 260 (2004) 1

[27]P. Fornasiero, J. Kašpar, M. Graziani, Appl. Catal. B 22 (1999) L11 ;

[28] F. Fally, V. Perrichon, H. Vidal, J. Kaspar, G. Blanco, J. M. Pintado, S. Bernal, G. Colon, M. Daturi, J.C. Lavalley, Catal. Today 59 (2000) 373

[29] J. Fan, X. Wu, R. Ran, D. Weng Appl. Surf. Sci., 245 (2005) 162

[30] E.C. Corbos, X. Courtois, N. Bion, P. Marecot, D. Duprez, Appl. Catal. B 80 (2008) 62

[31] M.Waqif, P. Bazin, O. Saur, J.C. Lavalley, G. Blanchard, O. Touret, Appl. Catal. B 11 (1997) 193

[32] W.S. Epling, A. Yezerets, N.W. Currier, Appl. Catal. B 74 (2007) 117

[33] P. Koci, F Plat, Jstepanek, M. Kubicek, M. Marek Catal. Today 137 (2008) 253 